Prepared in cooperation with the Lower Brule Sioux Tribe

\title{
Shoreline Erosion at Selected Areas Along Lake Sharpe on the Lower Brule Reservation in South Dakota, 1966-2015
}

Scientific Investigations Report 2018-5058
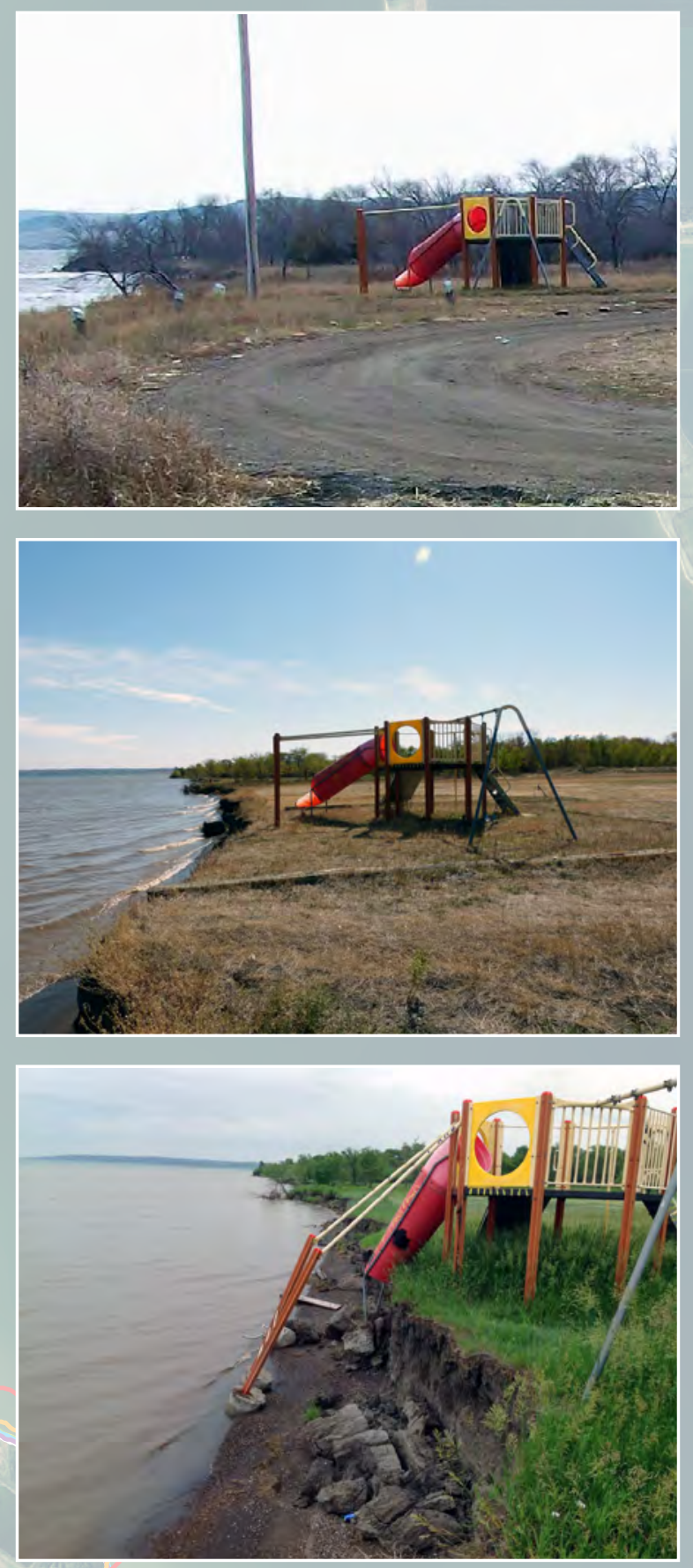
Cover. Background is modified from figure 2 showing shoreline traces from imagery for the 7 -mile reach on Lake Sharpe near Lower Brule, South Dakota.

Top photo: Shoreline adjacent to playground equipment at Lower Brule, South Dakota, November 9, 2010. Photograph by Kathleen Neitzert.

Middle photo: Shoreline near playground equipment at Lower Brule, South Dakota, October 3, 2012. Photograph by Kathleen Neitzert.

Bottom photo: Shoreline undercutting playground equipment at Lower Brule, South Dakota, June 20, 2013. Photograph by Kathleen Neitzert. 


\section{Shoreline Erosion at Selected Areas Along Lake Sharpe on the Lower Brule Reservation in South Dakota, 1966-2015}

By Ryan F. Thompson and John F. Stamm

Prepared in cooperation with the Lower Brule Sioux Tribe

Scientific Investigations Report 2018-5058 


\section{U.S. Department of the Interior \\ RYAN K. ZINKE, Secretary}

\section{U.S. Geological Survey James F. Reilly II, Director}

\section{U.S. Geological Survey, Reston, Virginia: 2018}

For more information on the USGS - the Federal source for science about the Earth, its natural and living resources, natural hazards, and the environment-visit https://www.usgs.gov or call 1-888-ASK-USGS.

For an overview of USGS information products, including maps, imagery, and publications, visit https://store.usgs.gov.

Any use of trade, firm, or product names is for descriptive purposes only and does not imply endorsement by the U.S. Government.

Although this information product, for the most part, is in the public domain, it also may contain copyrighted materials as noted in the text. Permission to reproduce copyrighted items must be secured from the copyright owner.

Suggested citation:

Thompson, R.F., and Stamm, J.F., 2018, Shoreline erosion at selected areas along Lake Sharpe on the Lower Brule Reservation, South Dakota, 1966-2015: U.S. Geological Survey Scientific Investigations Report 2018-5058, 29 p., https://doi.org/10.3133/sir20185058.

ISSN 2328-0328 (online) 


\section{Contents}

Acknowledgments ……..................................................................................................................

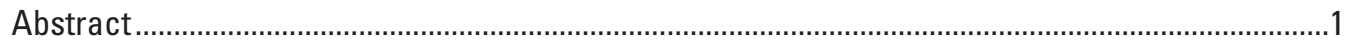

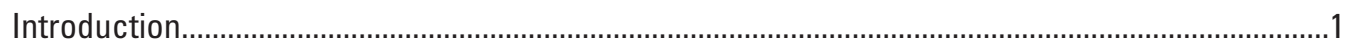

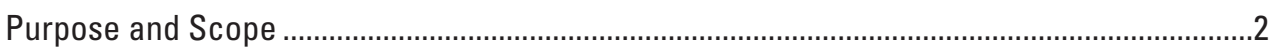

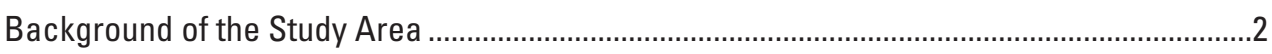

History of the Big Bend Dam and Lake Sharpe ……......................................................

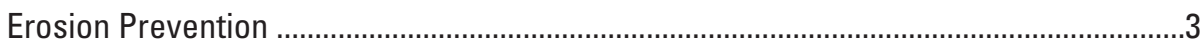

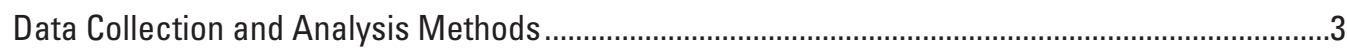

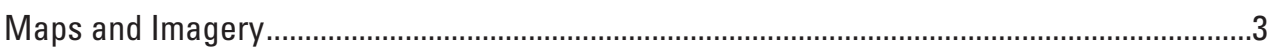

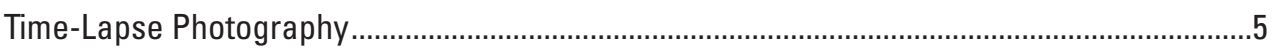

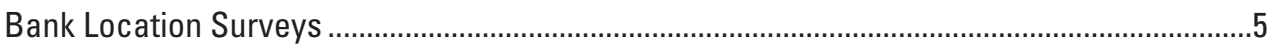

Global Navigation Satellite System Surveys ...................................................................

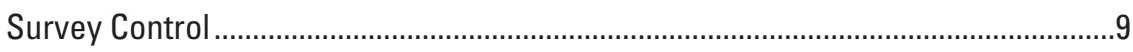

Quality Control of Survey Data .....................................................................................

Tripod-Based Light Detection and Ranging Surveys ........................................................

Drone Flights......................................................................................................................

Available Data from Other Sources .....................................................................................11

Reservoir Elevation Changes ........................................................................................12

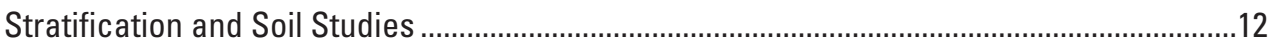

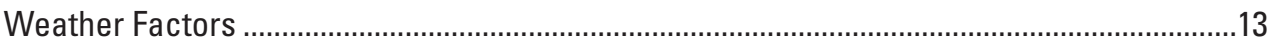

Air Temperature ................................................................................................ 13

Wind

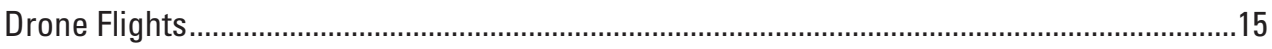

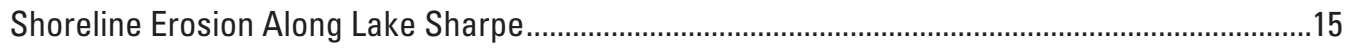

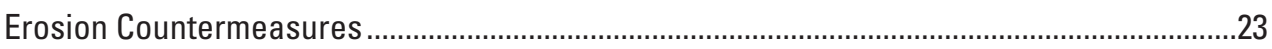

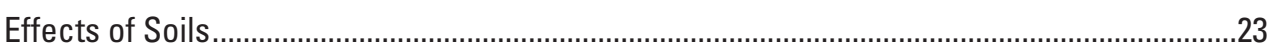

Summary

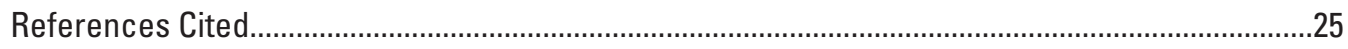

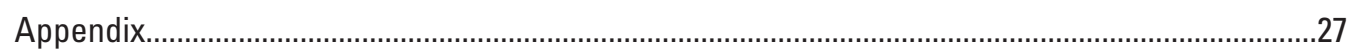

Shoreline Base Map Generated from Drone Imagery..........................................................28

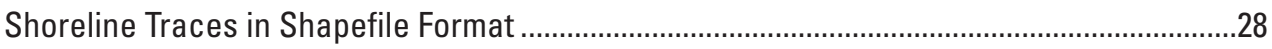

Global Navigation Satellite System Survey Data in Shapefile Format...................................28

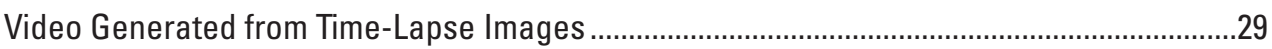

Plate 1. Soil Type and Land Cover Interactions with Erosion Measurements near Lower Brule, South Dakota ...........................................................................................29 


\section{Plate}

[Available for download from https://doi.org/10.3133/sir20185058]

1. Soil type and land cover interactions with erosion measurements near Lower Brule, South Dakota

\section{Figures}

1. Map showing location of the survey reaches on Lake Sharpe near Lower Brule, South Dakota

2. Map showing shoreline traces from imagery for the 7-mile reach on Lake Sharpe near Lower Brule, South Dakota.

3. Map showing locations of evaluation lines used in map and imagery analysis for the 7-mile reach on Lake Sharpe near Lower Brule, South Dakota.

4. Map showing locations of time-lapse cameras and light detection and ranging sites on the 7-mile reach of Lake Sharpe near Lower Brule, South Dakota.

5. Image showing multiresolution light detection and ranging scan near the playground site near Lower Brule, South Dakota, February 28, 2011.

6. Image showing light detection and ranging scan of a high-bank area near Lower Brule, South Dakota, March 1, 2011

7. Photograph showing a small, unmanned aerial system used to collect imagery data of the shoreline near Lower Brule, South Dakota.

8. Photograph showing surveying a target used to georeference images from the drone.

9. Image showing a still capture from the drone video showing the shoreline near Lower Brule, South Dakota, and a target used in georeferencing.

10. Graph showing daily mean reservoir elevation data for June 1, 2012, through April 4, 2014, on Lake Sharpe, South Dakota.

11. Graph showing hourly reservoir water elevation data for July 2013 on Lake Sharpe, South Dakota.

12. Map showing soil types in the 7-mile reach of Lake Sharpe near Lower Brule, South Dakota

13. Photograph showing ice build-up caused by wave action on Lake Sharpe near Lower Brule, South Dakota

14. Photograph showing mounded soils caused by ice heave at Lake Sharpe near Lower Brule, South Dakota

15. Map showing locations of weather stations near Lower Brule, South Dakota...

16. Graph showing average daily temperature from the Kennebec, South Dakota, weather station by Julian day of the year, 1893 to 2014 .

17. Graph showing average daily temperature from the Gann Valley, South Dakota, weather station by Julian day of the year, 1897 to 2009.

18. Graph showing wind direction at Big Bend Dam, South Dakota, January 1 through December 31, 2013, based on hourly record.

19. Graph showing cumulative erosion by time step by evaluation line from map and imagery analysis for Lake Sharpe near Lower Brule, South Dakota

20. Map showing erosion countermeasures along Lake Sharpe near Lower Brule, South Dakota 


\section{Tables}

1. Codes used to identify bank points surveyed ...............................................................

2. Cumulative erosion by evaluation line used in map and imagery analysis for the 7-mile reach on Lake Sharpe near Lower Brule, South Dakota

3. Average annual erosion from map and imagery analysis for Lake Sharpe near Lower Brule, South Dakota

4. Annual erosion at three shoreline locations from real-time kinematic bank surveys on Lake Sharpe near Lower Brule, South Dakota

5. Incremental erosion between imagery dates by evaluation line used in map and imagery analysis for Lake Sharpe near Lower Brule, South Dakota

\section{Conversion Factors}

U.S. customary units to International System of Units

\begin{tabular}{|c|c|c|}
\hline Multiply & By & To obtain \\
\hline \multicolumn{3}{|c|}{ Length } \\
\hline inch (in.) & 2.54 & centimeter $(\mathrm{cm})$ \\
\hline inch (in.) & 25.4 & millimeter (mm) \\
\hline foot $(\mathrm{ft})$ & 0.3048 & meter $(\mathrm{m})$ \\
\hline mile (mi) & 1.609 & kilometer (km) \\
\hline \multicolumn{3}{|c|}{ Area } \\
\hline acre & 4,047 & square meter $\left(\mathrm{m}^{2}\right)$ \\
\hline acre & 0.4047 & hectare (ha) \\
\hline acre & 0.4047 & square hectometer $\left(\mathrm{hm}^{2}\right)$ \\
\hline acre & 0.004047 & square kilometer $\left(\mathrm{km}^{2}\right)$ \\
\hline \multicolumn{3}{|c|}{ Volume } \\
\hline cubic yard $\left(\mathrm{yd}^{3}\right)$ & 0.7646 & cubic meter $\left(\mathrm{m}^{3}\right)$ \\
\hline
\end{tabular}

Temperature in degrees Fahrenheit $\left({ }^{\circ} \mathrm{F}\right)$ may be converted to degrees Celsius $\left({ }^{\circ} \mathrm{C}\right)$ as follows:

$$
{ }^{\circ} \mathrm{C}=\left({ }^{\circ} \mathrm{F}-32\right) / 1.8 \text {. }
$$

\section{Datum}

Vertical coordinate information originating with the U.S. Geological Survey and presented in this report is referenced to the North American Vertical Datum of 1988 (NAVD 88) computed using Geoid09 from the North American Datum of 1983 (NAD 83; CORS96, epoch 2002.0000).

Vertical coordinate information originating with the U.S. Army Corps of Engineers and presented in this report is referenced to Mean Sea Level (MSL) Datum.

Horizontal coordinate information is referenced to the NAD 83 (CORS96, epoch 2002.0000).

Altitude, as used in this report, refers to distance above the vertical datum. 


\section{Abbreviations}

$\begin{array}{ll}\text { DO00 } & \text { Digital Orthophoto Quarter Quadrangle } \\ \text { geo pdf } & \text { georeferenced portable document file } \\ \text { GNSS } & \text { global navigation satellite system } \\ K & \text { soil erodibility factor } \\ \text { LBST } & \text { Lower Brule Sioux Tribe } \\ \text { lidar } & \text { light detection and ranging } \\ \text { NAIP } & \text { National Agricultural Imagery Program } \\ \text { OLC } & \text { Oglala Lakota College } \\ \text { OPUS } & \text { Online Positioning User Service } \\ \text { RTK } & \text { real-time kinematic } \\ \text { SSURG0 } & \text { Soil Survey Geographic } \\ \text { USGS } & \text { U.S. Geological Survey }\end{array}$

\section{Acknowledgments}

The authors would like to extend thanks to cooperating individuals that assisted with data collection and processing efforts, including Vaughn Big Eagle and Darrel Middletent, Jr., of the Environmental Protection Office of the Lower Brule Sioux Tribe, and James Sanovia of the Math and Science Department at Ogallala Lakota College.

Gratitude also is expressed to the numerous U.S. Geological Survey students and staff involved. We hope that the opportunity to do science in a beautiful and unique area of the State compensated for the freezing winter temperatures and summer rattlesnake hazards all of us endured. 


\title{
Shoreline Erosion at Selected Areas Along Lake Sharpe on the Lower Brule Reservation in South Dakota, 1966-2015
}

\author{
By Ryan F. Thompson and John F. Stamm
}

\section{Abstract}

The Lower Brule Reservation in central South Dakota is losing land because of shoreline erosion along Lake Sharpe, a reservoir on the Missouri River, which has caused detrimental effects for the Lower Brule Sioux Tribe including losses of cultural sites, recreation access points, wildlife habitat, irrigated cropland, and landmass. To better understand and quantify shoreline erosion, the Lower Brule Sioux Tribe and the U.S. Geological Survey cooperated on a series of datacollection efforts and study of shoreline erosion along Lake Sharpe. Data collected or compiled for 1966-2015 were used to describe and quantify shoreline erosion along Lake Sharpe. The progression of shoreline erosion near the community of Lower Brule, South Dakota, was tracked by comparing current or recent aerial imagery with existing historical maps. At 33 evaluation lines along a 7-mile reach of Lake Sharpe shoreline near Lower Brule, cumulative change of shoreline from 1966 to 2010 ranged from about -224 feet of deposition to 770 feet of erosion.

Photographic and location data were collected for this study to understand the processes affecting erosion and estimate erosion rates. Photographs were collected only in the 7-mile reach near Lower Brule, but locations of the bank over time were collected at the 7-mile reach and two additional reaches within the Lower Brule Reservation. Global navigation satellite system equipment was used in real-time kinematic mode to collect bank locations along three reaches of interest. Reach-length data were collected four times between November 2011 and November 2012. A small, unmanned aerial system (drone) was used to capture digital video along the shoreline of the 7-mile reach.

Water-level fluctuations contribute to the number of wet-dry cycles experienced by the soils at the shoreline or bank. The soils present under the current (2017) location of the reservoir are predominantly terrace alluvium, consisting of sand and silt. Detailed soils data for Lyman County indicate that the dominant soil type along the southern part of the shoreline in the 7-mile reach is Bullcreek clay. Weather within the study area can affect the erosion rate. Air temperature can potentially affect erosion rates by freezing and thawing water and soils. Mean hourly wind speeds vary somewhat throughout the year but averaged 13.3 miles per hour. The direction of prevailing winds near Lower Brule indicates that there are several miles of fetch to build large waves.

Annual erosion rates calculated or measured throughout this study varied by location. Long-term annual average erosion rates of the 7-mile reach, as calculated by image analysis, ranged from -5.1 feet per year (deposition) to 17.5 feet per year (erosion). Short-term annual erosion rates measured using global navigation satellite system equipment during 2010-12 ranged from about 0 to 31.7 feet per year for the 7-mile reach. Existing scour countermeasures have been effective variably. Fieldstone rip-rap seems to have stabilized the shoreline, whereas tree strips paralleling the shoreline seem to have slowed erosion.

\section{Introduction}

The Lower Brule Reservation in central South Dakota is losing land because of shoreline erosion along Lake Sharpe (fig. 1), a reservoir upstream from Big Bend Dam on the Missouri River. This loss of land area has affected the Lower Brule Sioux Tribe (LBST) detrimentally, including losses of cultural sites, recreation access points, wildlife habitat, irrigated cropland, and landmass (Thompson, 2014). Cultural sites have been disturbed and destroyed. Recreation access points have disappeared as the edge of water advances landward. The resulting nearshore areas are shallow for a great distance from shore and make it difficult for boats to reach shore in many areas. Recreational hunting opportunities have been lost as wildlife habitat erodes away. The sediment load created by collapsing banks has affected the water quality and surface-water intake structure of the water treatment plant in the community. Agricultural range, hay ground, and crop ground have been lost.

To better understand and quantify shoreline erosion, the LBST and the U.S. Geological Survey (USGS) cooperated on a series of data-collection efforts and study of shoreline erosion along Lake Sharpe. From 2010 through 2015, the shoreline configuration was mapped at selected locations using a variety of methods. Bank surveys, unmanned aerial system (drone) flights, a bathymetric survey, and trail cameras were 


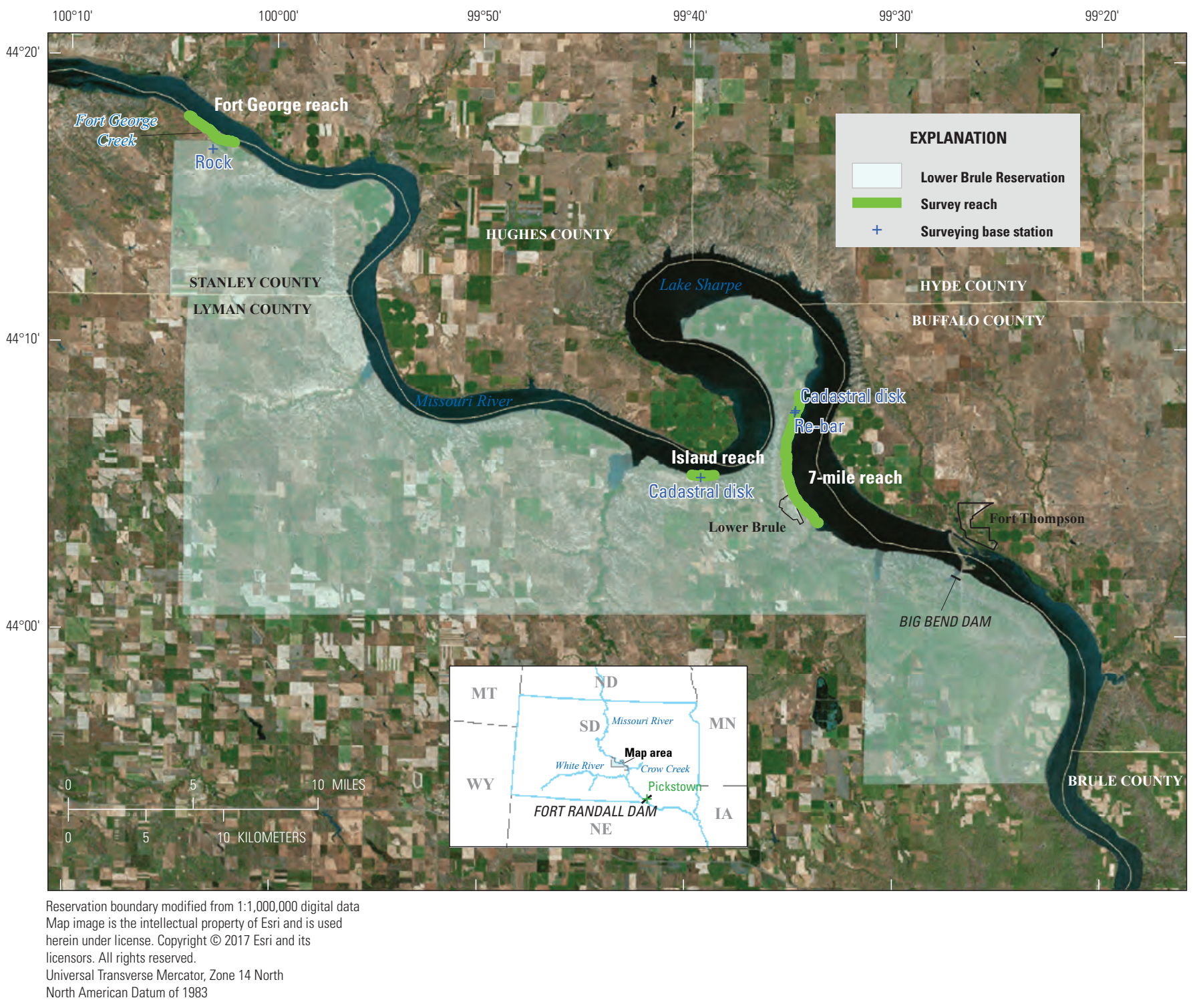

Figure 1. Location of the survey reaches on Lake Sharpe near Lower Brule, South Dakota.

used to collect erosion data. The bathymetric survey maps were published previously (Thompson, 2014) and included data interpretation. The bathymetric survey data along with other data collected or compiled for 1966-2015 were used to describe and quantify shoreline erosion along Lake Sharpe, as presented herein.

\section{Purpose and Scope}

The purpose of this report is to describe and quantify shoreline erosion at selected locations along Lake Sharpe on the Lower Brule Reservation. Data used in the analyses were collected for various efforts from 2010 through 2015. In addition, imagery and maps for the Lower Brule area from 1966, 1991, 2004, 2005, 2006, 2008, and 2010 were available, enabling analysis of shoreline erosion for 1966-2015. The information presented in this report provides a description and quantification of the shoreline erosion that can be used by the LBST and others to explore management options to better protect resources on the Lower Brule Reservation.

\section{Background of the Study Area}

The Missouri River and its associated lowlands and flood plains have been important to the LBST since long before European settlement in the area. In fact, the translation of the Lakota name for the Tribe, "Kul Wicasa," indicates that they are a people who live in the lowlands. Although the LBST historically resided near the mouth of the White River, the Act of 1889 compelled them to relocate north along the Missouri 
River from Fort George Creek to opposite Crow Creek (Brian Molyneaux, LBST, written commun., 2017). Here, they continue living adjacent to the rich variety of resources available in the valley bottom.

\section{History of the Big Bend Dam and Lake Sharpe}

The Flood Control Act of 1944 (P.L. 78-534) implemented the Pick-Sloan Missouri Basin Program, which authorized construction of two dams that affected LBST (Ferrell, 1993). The Fort Randall Dam near Pickstown, South Dakota, and the Big Bend Dam near Fort Thompson, S. Dak. (fig. 1), ultimately flooded the lowlands that were the basis of the LBST's way of life (Brian Molyneaux, LBST, written commun., 2017). Construction on Big Bend Dam began in 1959. The dam is named for a 25 -mile river loop forming a unique bend on the Missouri River, about 7 miles upstream from the community of Lower Brule, S. Dak. (U.S. Army Corps of Engineers [USACE], 2015a). The impoundment for Big Bend Dam is Lake Sharpe, which was named for former governor, Merrill Sharpe, for his instrumental role in implementing construction of the Missouri River dams in South Dakota. Before filling, the communities of Lower Brule and nearby Fort Thompson were relocated from their original flood plain locations to their current upland locations in the early 1950s. The dam was closed July 24, 1963, and reservoir filling began in November 1963 (USACE, 2015b). The reservoir pool reached minimum operating levels the following March.

Some of the benefits of Lake Sharpe to LBST include additional fishing and recreational opportunities, and additional waterfowl habitat. The community of Lower Brule uses Lake Sharpe as the source for its water supply and for irrigation for crops grown along the shore. Lake Sharpe is managed jointly for flood control, irrigation, and hydropower. Its watersurface elevation is held relatively stable throughout most of the year (National Park Service, 2015), although diurnal fluctuations are possible because dam releases are changed in response to hydropower demands.

\section{Erosion Prevention}

After Lake Sharpe was filled completely in 1964, the adjacent landscape changed primarily through erosional processes at the shoreline of the reservoir. Erosion countermeasures of various types have been tried in different locations. Archaeological explorations in the Big Bend Dam area have recorded more than 150 village sites (National Park Service, 2015), and some of these sites are being affected by these landscape changes. Shoreline erosion in the Fort George reach of Lake Sharpe (fig. 1) had been washing away an important cultural site, and rip-rap was placed along this reach in 2005 in an effort to mitigate the erosion. Erosion at a second cultural site in the Island reach (fig. 1) was reduced by the construction of an offshore island in 2007 that runs parallel to the shoreline. The island itself is protected with rip-rap and vegetation, and helps protect the shoreline by diverting the current away from the shore and reducing wave action. The island also was designed to provide backwater habitat (South Dakota State Historical Society, 2008) and has been planted with trees in an effort to re-establish forest habitat that was largely lost when the reservoir filled. Shoreline erosion near Lower Brule was affecting the community's water supply in two ways. As the shoreline collapsed and was broken up by wave action, the resulting sediment load increased water treatment costs. Sediment build up made it necessary to extend the intake structure farther out into the reservoir on multiple occasions, also adding expense. In an effort to reduce these sediment-related problems, a reach of shoreline near the intake for the water treatment plant was protected using rip-rap and gabion baskets in 2010. In several other locations, concrete rubble was placed on the shoreline to reduce erosion around boat ramps and other lakeside use areas.

\section{Data Collection and Analysis Methods}

The following sections describe the methods used in the various data collection and analysis efforts completed to document and quantify shoreline erosion. Separate descriptions are presented for shoreline erosion data collection from maps and imagery, time-lapse photography, bank location surveys, and unmanned aerial system (drone) flights.

\section{Maps and Imagery}

The progression of shoreline erosion near Lower Brule, S. Dak., can be tracked by comparing current or recent aerial imagery with existing historical maps. By measuring the distance between the shoreline locations in maps or images from different dates, cumulative and incremental erosion rates can be calculated. Aerial imagery for the shoreline along Lower Brule can be visualized using internet-based mapping services such as Google Earth ${ }^{\mathrm{TM}}$ Pro (available for download at https://www.google.com/earth/desktop/). However, for this analysis, georeferenced imagery and a map were downloaded and displayed in $\operatorname{ArcGIS}^{\circledR}$ software (Esri, 2015), where lines were digitized tracing the shoreline locations. Georeferenced imagery and map dates downloaded for the Lower Brule area include 1966, 1991, 2004, 2005, 2006, 2008, and 2010. These shoreline traces are shown on figure 2 and are available as a shapefile in the data release associated with this report (Thompson and others, 2018) that can be accessed at https://doi.org/10.5066/F7H130XV. A description of the shapefiles included in the data release is given in the appendix at the end of this report. The 1966 map was available as the USGS 7.5-minute quadrangle topographic map (USGS, 2017). This date was chosen because it represents a baseline of the shore location shortly after Lake Sharpe was filled in 1964. The 1991 date was available as a Digital Orthophoto Quarter Quadrangle (DOQQ; USGS, 2015), and all other 


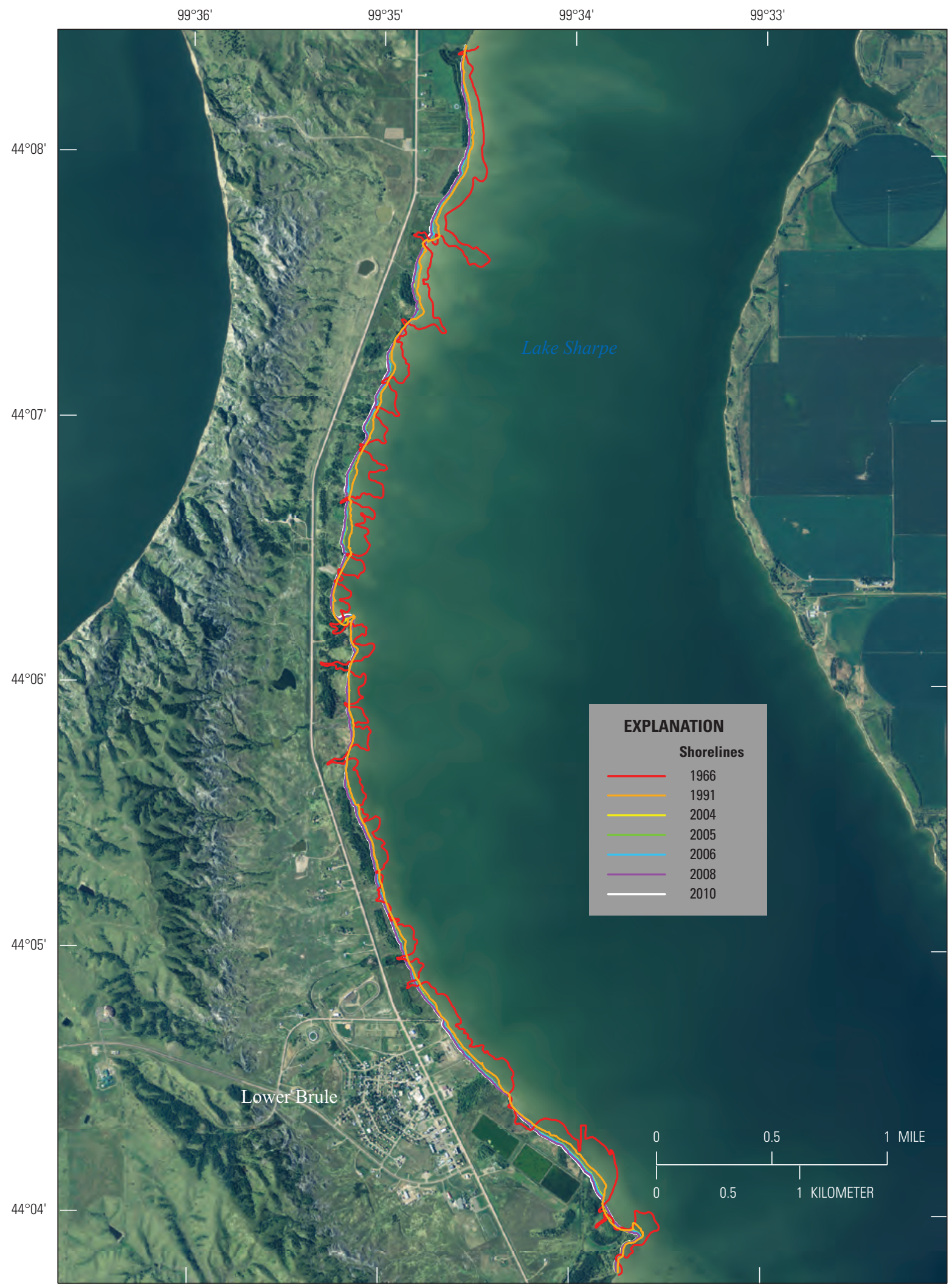

Imagery from National Agricultural Imagery Program, 2010 North American Datum of 1983

Figure 2. Shoreline traces from imagery for the 7-mile reach on Lake Sharpe near Lower Brule, South Dakota. 
images were from the National Agricultural Imagery Program (U.S. Department of Agriculture, 2013). The shoreline from each image was digitized and attributed with a name representing the imagery year and the date the image was captured, if known. By comparing the location of the shoreline traces for the available image dates, it is possible to track the progression of shoreline erosion over time. However, it is necessary to understand the limitations of the georeferencing accuracy when interpreting the changes in shoreline locations over time. For the shoreline traces digitized in this effort, the shoreline shown in the 1966 quadrangle map is considered baseline. All shoreline traces were digitized while zoomed in to $1: 1,400$ or closer to minimize inaccuracies associated with scale. The 1991 DOQQ image has a ground sample distance of about 3.3 feet per pixel (USGS, 1996b), but georeferencing may have a root mean square error of as much as 23 feet (USGS, 1996a). The National Agricultural Imagery Program imagery collected through 2005 was georeferenced by matching locations of objects visible in existing DOQQ imagery. The standard was that objects needed to be within 16.4 feet of the DOQQ, but in 2006 and later objects were referenced to a true ground system. In this true ground system, 95 percent of points must be within 19.7 feet of true ground (U.S. Department of Agriculture, 2013). Given these accuracies, small changes in shoreline locations between successive years may be overwhelmed by georeferencing errors, but in areas where large amounts of erosion are measured over multiple years, georeferencing errors may be less of a factor.

To evaluate shoreline erosion between imagery dates, 33 evaluation lines on the 7-mile reach of the Lake Sharpe shoreline near Lower Brule, S. Dak., were set up generally perpendicular to the shoreline at intervals of about 0.16 to 0.21 miles (fig. 3). Evaluation lines were placed intentionally at locations that were not within a cove of the 1966 shoreline because these locations tended to silt in rather than erode. Measurements were made along the evaluation lines between the trace of the 1966 shoreline and each of the shoreline traces from other imagery dates.

\section{Time-Lapse Photography}

In an effort to better understand the erosional processes involved, automatic cameras were deployed at three locations along the 7-mile reach of shoreline near Lower Brule, S. Dak. (fig. 4). The cameras were mounted on a pole or tree that allowed the camera to frame a stretch of shoreline. Photos were automatically taken at 6-hour intervals and timestamped. The photos were downloaded periodically, and the best daylight photo at each site each day was selected to represent that site for that day. Adobe Photoshop software (Adobe, 2017) was used to display the selected photos sequentially at 10 frames per second and record as a video. Time-lapse videos (in .mp4 format) generated from each of the three cameras are included in the data release for this report (Thompson and others, 2018). A description also is provided in the appendix of this report. The videos can be viewed by downloading the files and playing them in any media player capable of playing .mp4 format.

At two of the sites (lagoon and lodge; fig. 4), the cameras needed to be moved because the trees they were mounted on became in danger of toppling into Lake Sharpe. Some days of photos were missed until the cameras could be remounted in a new location and begin capturing shoreline images again. Because a somewhat different field of view was framed after the cameras were moved, two videos (one before and one after the move) were used to display the images at each of these two sites.

\section{Bank Location Surveys}

Bank location surveys were completed to identify the coordinates of the top edge of the bank along Lake Sharpe. Then, surveys were repeated at various time intervals, allowing erosion rates to be calculated. Global navigation satellite system (GNSS) equipment was used to track erosion in a linear format, such that erosion rates for a point could be calculated in feet per year. Over a specific reach of shoreline, erosion rates also can be expressed in terms of acres lost per year. In collaboration with Oglala Lakota College (OLC), tripod-based light detection and ranging (lidar) equipment was used with the intent to estimate volume of erosion, expressed in cubic yards of soil eroded during the period between two surveys.

\section{Global Navigation Satellite System Surveys}

GNSS equipment was used in the real-time kinematic (RTK) mode to collect bank locations along each of the three reaches of interest (fig. 1). The first reach, called the Fort George reach, was near historic Fort George and underwent high erosion rates that were threatening cultural resources and irrigation systems. The second reach, called the Island reach, was monitored to track erosion at and near a constructed island, which was designed to protect a cultural site from erosion and provide backwater habitat. The third reach, called the 7-mile reach, consisted of 7 miles of shoreline near Lower Brule and was monitored to track erosion of wildlife habitat and lakeside access areas affecting the water supply intake and threatening the municipal sewage lagoons. The 7 -mile reach was the site of primary importance and received the most regular bank surveys. During each survey, point data were collected at the top edge of the bank and at other pertinent locations. At the 7-mile reach, lines were digitized connecting points that represent the edge of bank so that bank erosion between survey dates could be visualized more easily. Shapefiles of the point data for all three reaches and the edge of bank lines for the 7-mile reach are available in the data release associated with this report (Thompson and others, 2018). Descriptions of the shapefiles within this data release also are listed in the appendix at the end of this report. 


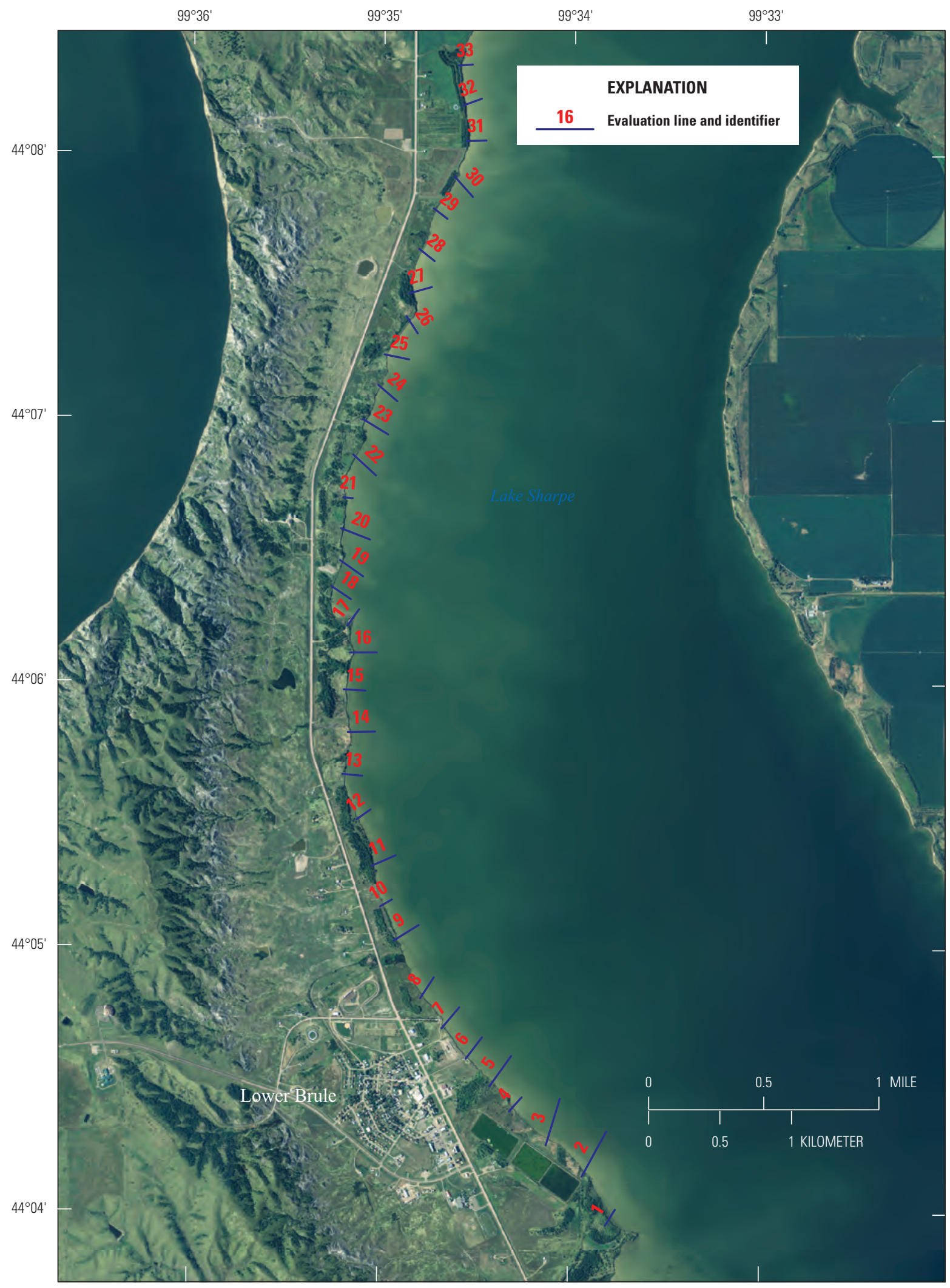

Imagery from National Agricultural Imagery Program, 2010

North American Datum of 1983

Figure 3. Locations of evaluation lines used in map and imagery analysis for the 7-mile reach on Lake Sharpe near Lower Brule, South Dakota. 


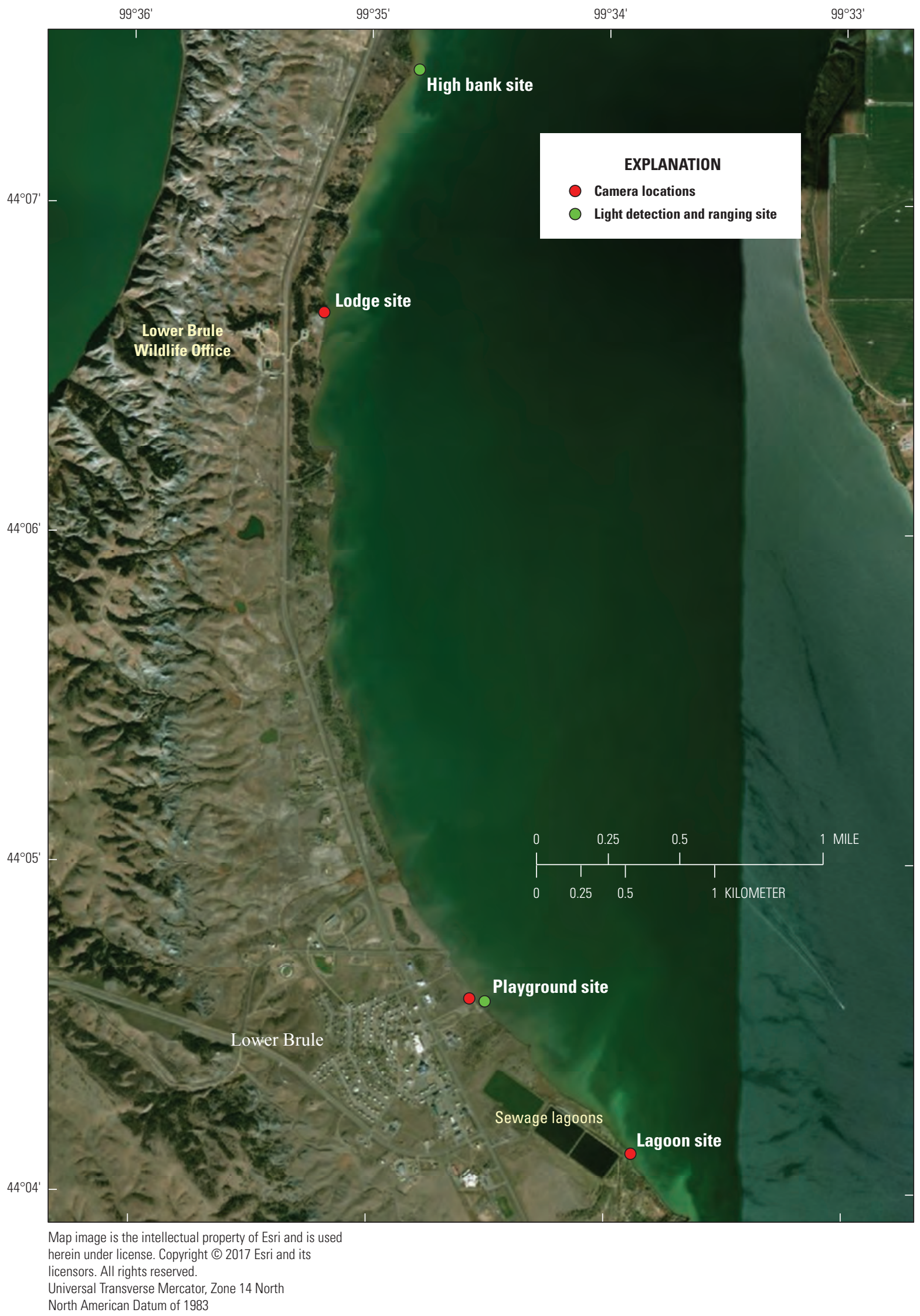

Figure 4. Locations of time-lapse cameras and light detection and ranging sites on the 7-mile reach of Lake Sharpe near Lower Brule, South Dakota. 
In RTK mode, a stationary base receiver uses a radio to transmit differential correction signals in real time to one or more mobile receivers (rovers), which are used to collect data on objective points. This correction signal allows a faster and more accurate determination of horizontal and vertical coordinates than would be possible using a single receiver. In static mode, a stationary receiver collects information from multiple GNSS satellites simultaneously and stores these data as a file. The file can be processed using the National Geodetic Survey's Online Positioning User Service (OPUS; National Geodetic Survey, 2016) to determine the coordinates of the location occupied. Static methods were used primarily to set up control points within the study area, whereas RTK methods generally were used to determine locations of points along the bank. The surveying methods used in this study met the criteria for a level IV GNSS survey (Rydlund and Densmore, 2012).

To determine the location of a given point in RTK mode, the 6.56-foot rover pole with a topo boot at the bottom was held vertically (using a bird's-eye level) on the point for 3 seconds. The average horizontal and vertical coordinates for the period are then stored in a hand-held survey controller, along with a user-selected code describing the objective point. Because the horizontal location of the edge of water will change with pool elevation and can be difficult to estimate because of wave action, the edge of water typically was not mapped. Instead, the top edge of the bank was mapped. Codes also were used to describe the bank configuration, such as if it was undercut or covered with weed-suppression fabric. Other features were occasionally found, mapped, and described with codes, such as cracks along the bank, broken-off pieces of the bank, bank slumps, and mounds of soil caused by prior ice heaves. The distance between objective points collected varied with the uniformity and shape of the bank and over time as the study progressed.

The first RTK surveys were done in the 7-mile reach in November 2010 and March 2011. During these initial surveys, bank points were collected only near specific sites and tended to be spaced variably. Reach-length data were collected four times in the 7-mile reach between November 2011 and November 2012. After the quarterly surveys, bank locations were collected in July 2013 on transects that were laid out for a bathymetric survey of the nearshore areas of the 7-mile reach (Thompson, 2014). A final round of surveying was completed along the 7-mile reach in November 2015. In conjunction with the four 2011-12 quarterly surveys at the 7-mile reach, five surveys were completed in the Fort George reach in November 2011, and February, May, August, and November 2012. Three surveys also were completed at the Island reach in November 2011, and May and November 2012.

Depending on what was required to adequately capture the shape of the edge of the bank, the distance between adjacent points collected at all three reaches during surveys done between November 2011 and November 2012 and during November 2015, ranged from less than 1 foot to 3 feet. In locations where a bank was not present (for example, at a gradually sloping beach or where rip-rap was in place), points were either labeled appropriately or not collected in that location. A description of codes used to identify the type of point surveyed is given in table 1 . In a few locations, bank points could not be collected because thick brush or trees blocked access to the edge of the bank, or interfered with satellite reception, preventing the RTK equipment from receiving a clear signal. In other locations, the bank was crumbling severely, and large cracks made it unsafe to approach close enough to collect a point.

Table 1. Codes used to identify bank points surveyed.

\begin{tabular}{ll}
\hline \multicolumn{1}{c}{ Code } & \multicolumn{1}{c}{ Description } \\
\hline Bank & An approximately vertical soil surface exposed adjacent to the edge of water. \\
Beach & A gradually sloping soil surface descending to the edge of water. \\
BM & A benchmark disk not found in the National Geodetic Survey's database. \\
Brkoff & A large section of soil that has broken off from the rest of the bank and fallen at least partially into the water. \\
Cement & Reclaimed concrete slabs used to armor the soil from wave action and erosion. \\
Crack & A fissure in the bank, often running parallel to the edge of the bank. \\
Drape & An extremely undercut bank, with the edge drooping down towards the water. \\
Gully & Bank on a small gulch extending landward, usually where a small tributary drainage enters the reservoir. \\
Heave & A linear pile of soil running generally parallel to the shoreline, formed when wind-driven ice heaves shoreline soils landward. \\
Net & Bank is covered by weed suppression fabric placed along a row of planted trees. \\
Riprap & A thick layer of field stone placed to armor the soil from wave action and erosion. \\
Slump & A section of bank that has separated and is sliding downslope towards the edge of water. \\
Test & A point collected to verify operation of the surveying equipment. \\
\hline
\end{tabular}




\section{Survey Control}

Few published benchmarks existed within the study area, and those present were not always in an easily accessible location or were otherwise unsuitable for use as a GNSS base. Vertical and horizontal control for data collection was established on reference points near each of the three reaches of interest. For the 7-mile reach near Lower Brule, a 4.75-hour static GNSS occupation on a nearby Bureau of Land Management cadastral disk (with no known published coordinates, but determined to be at latitude $44^{\circ} 7^{\prime} 49.64693^{\prime \prime}$ $\mathrm{N}$, longitude $99^{\circ} 34^{\prime} 45.65437^{\prime \prime} \mathrm{W}$; fig. 1) was processed using the OPUS (National Geodetic Survey, 2016). Using the cadastral disk as a base, 5-minute RTK occupations were completed to establish the coordinates of various reference marks, each consisting of a punch point in the end of a length of rebar driven into the ground. One of these reference marks (fig. 1) was at the edge of a concrete pad near the cadastral disk. At the next site visit, the cadastral disk had been destroyed, so the nearby rebar (fig. 1) was used as control for the remainder of the study and is referred to as the base station for the 7-mile reach. The reference point for the Fort George reach was established in a divot point on a large boulder in a prominent location overlooking the Fort George area (labelled "rock" in fig. 1). A 4.40-hour static GNSS occupation was submitted to OPUS, and the location was determined to be latitude $44^{\circ} 16^{\prime} 44.55807^{\prime \prime} \mathrm{N}$, longitude $100^{\circ} 3^{\prime} 5.46856^{\prime \prime} \mathrm{W}$. A Bureau of Land Management disk was present near the Island reach (fig. 1) and was used for a reference mark. A 2.46-hour static GNSS occupation was submitted to OPUS, and the location was determined to be latitude $44^{\circ} 5^{\prime} 27.17964^{\prime \prime} \mathrm{N}$, longitude 99 $39^{\prime} 20.07578^{\prime \prime} \mathrm{W}$. Additional static occupation files were collected on each of the GNSS base location points throughout the study to ensure that the points had not moved over time. Although elevation data are collected at each objective point, the horizontal coordinates of points on the bank were most critical for this study. Natural occurrences, such as a section of bank undergoing a slump, the sagging of a severely undercut bank, or the upheaval of the bank from ice, may cause bank elevation to change over time.

\section{Quality Control of Survey Data}

Measures were taken to determine if the reference marks used for RTK base locations were being affected by surface motion. The reference marks were periodically re-occupied, and static files collected and processed using OPUS, so that coordinates could be compared with those determined in previous occupations. Although slight changes were noted sometimes, corrections were not applied because the differences were negligible relative to the changes in bank location over time, and were well within the root mean square error associated with OPUS solutions (typically about 0.43 inch). Additionally, the bird's-eye levels used to position the base and rove poles were checked periodically for plumb and adjusted when necessary.

\section{Tripod-Based Light Detection and Ranging Surveys}

With equipment and staff assistance from the Math and Science Department of OLC, an effort was made to explore the use of tripod-based lidar equipment to estimate erosion volumes over time. Lidar scans were completed by first using RTK GNSS surveying methods to establish the locations of a point on the ice near shore, and two or more locations on the bank. The tripod-based lidar instrument was then set up over the point established on the ice, whereas reflective targets were set up on bipods over the points established on the shore. The lidar scan data could then be georeferenced using the known positions of the instrument and targets. An initial lidar scan of the bank at the playground site (fig. 4) was completed on February 28, 2011 (fig. 5). The same procedure was completed March 1, 2011, at a high bank site (fig. 4) within the 7-mile reach (fig. 6). Lidar data scans can be collected at different densities, as shown on figures 5 and 6. An initial, low-density scan was completed to gain an overview of the area. Using the field of view produced by the first scan, the extent of interest could be determined for a second scan using a higher point density. The lower-density scan is visible in figures 5 and 6 on about the lower one-third of the image. Bands of orange points in front of the bank, just to the right of the center, are shown in figure 6 . These points represent data collected on snowflakes that were resuspended by a gust of wind during the scan.

Followup lidar scans were planned for the following winter, allowing the bank surfaces to be compared over a 1-year time step; however, the winter of 2011-12 was very mild. Much of Lake Sharpe did not develop ice cover until late winter. The ice that did eventually form near the two lidar sites (fig. 4) was judged not thick or stable enough to safely hold the equipment and personnel required. Instead, a second set of lidar scans were completed March 5 and 6, 2013. During the 2011 and 2013 scans, snowdrifts obscured various parts of the bank at both sites. Although panoramic photos captured at the same time as the scans allowed OLC staff to identify areas where data points were on the surface of the snow, the obscured areas of the bank prevented comprehensive comparisons of the bank surfaces at both lidar datacollection sites.

\section{Drone Flights}

A small, unmanned aerial system, or drone (fig. 7), with an onboard natural-color camera, was used to capture digital video imagery along the shoreline of the 7-mile reach. The initial flights were completed in August 2011, and a similar effort was repeated in August 2012. The imagery captured from the drone was collected and postprocessed by the USGS National Unmanned Aircraft Systems Project Office (https:// uas.usgs.gov/index.shtml). The nose cone housing the camera was available in two configurations (vertically downward 


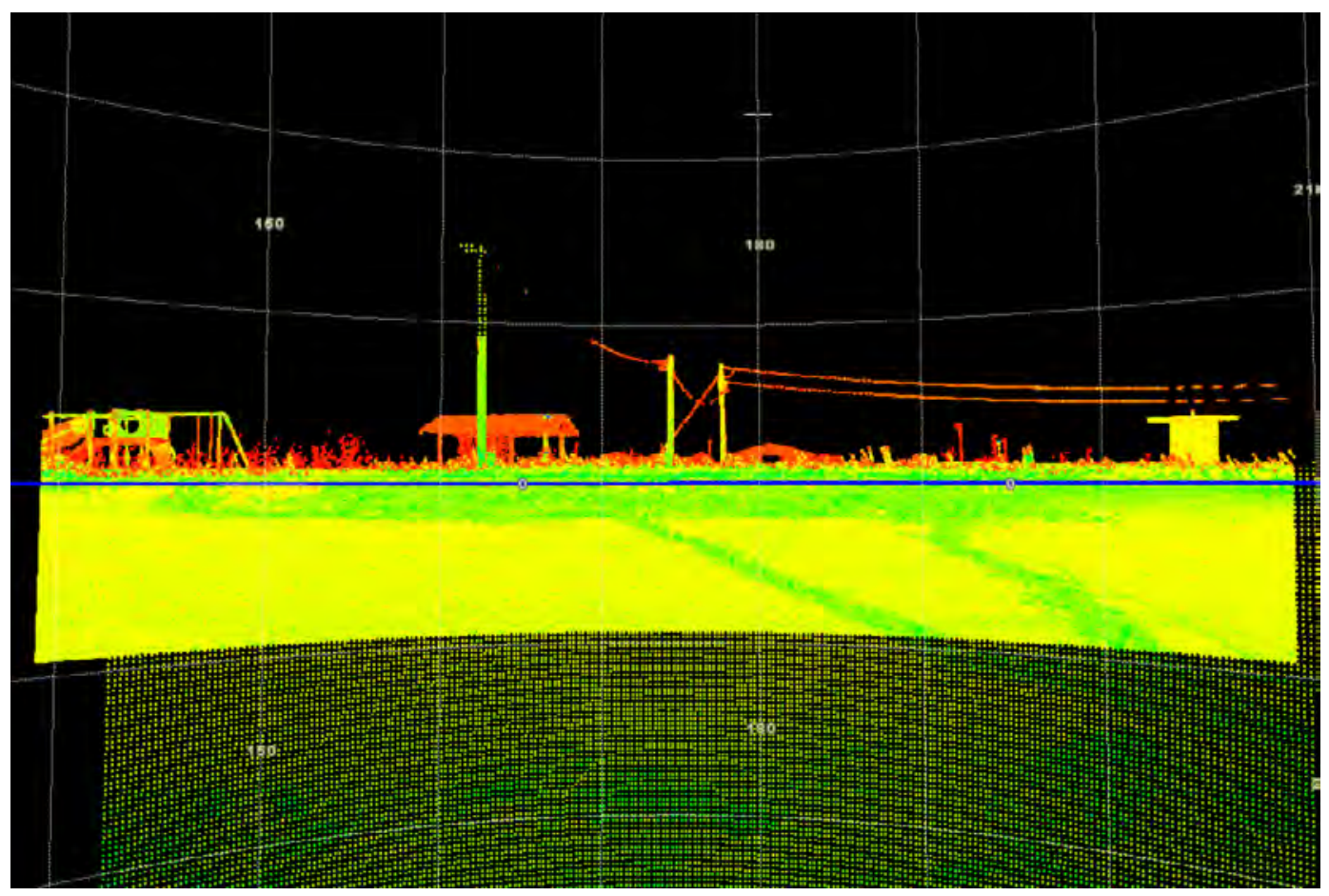

Figure 5. Multiresolution light detection and ranging scan near the playground site near Lower Brule, South Dakota, February 28, 2011.

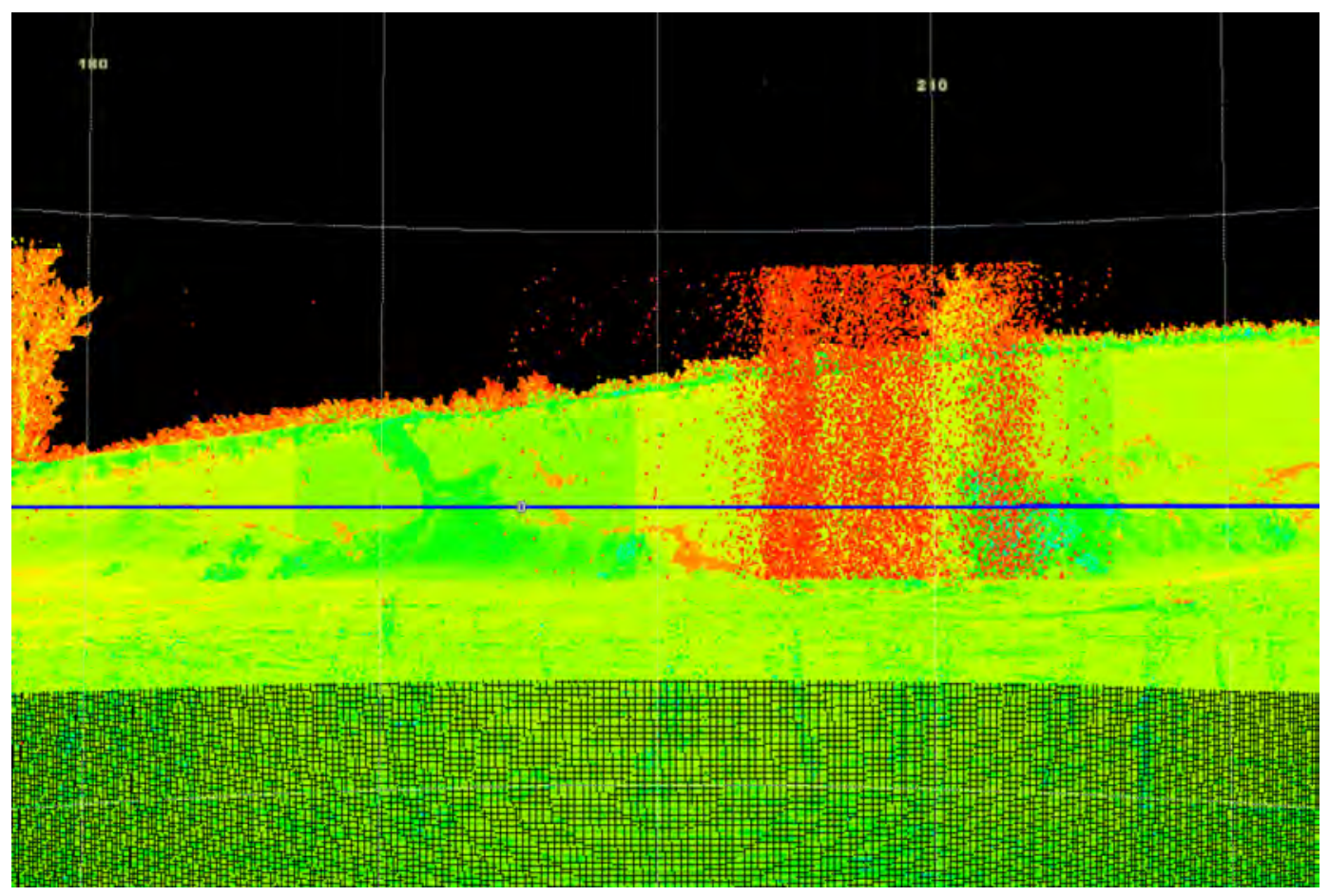

Figure 6. Light detection and ranging scan of a high-bank area near Lower Brule, South Dakota, March 1, 2011. 


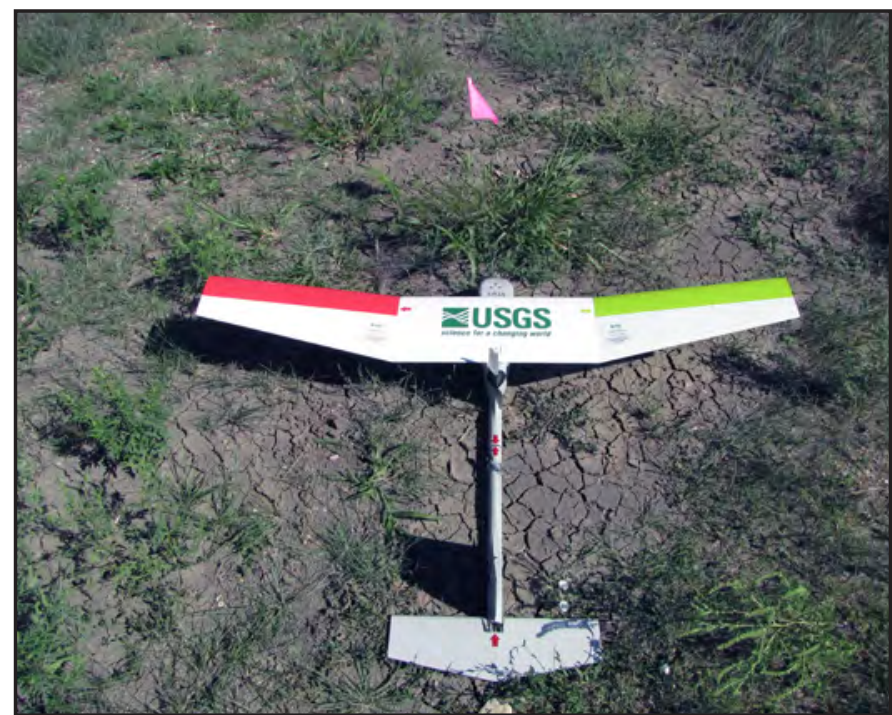

Figure 7. A small, unmanned aerial system (drone) used to collect imagery data of the shoreline near Lower Brule, South Dakota. Photograph by Kathleen Neitzert.

and side-looking), which allowed the video to be captured from differing perspectives. Still images could be generated from the video and used to compare shoreline conditions between dates. A set of information from the drone, including time, date, heading, approximate horizontal coordinates, and altitude are superimposed on the video. Before the drone flights, a series of targets were staked to the ground along the shoreline. The horizontal locations of the targets were determined using RTK GNSS surveying equipment (fig. 8), which allowed the images to be more accurately georeferenced (fig. 9).

The video and still images collected by the drone provide some of the same information as the time-lapse images but cover the entire 7-mile reach. The RTK survey data can show that the bank is eroding in a certain area, but the drone images can be used to determine if that area has a grassy or forested bank. The drone-based images also can indicate if trees that are falling into the water tend to stay at the shoreline (possibly providing a degree of protection from waves) or if they are transported through wave action. The data release for this report (Thompson and others, 2018) contains a link to download the base map constructed from drone imagery, which is described in the appendix at the end of this report.

\section{Available Data from Other Sources}

Data useful for erosion analysis are available from sources outside of this study. This section of the report describes and summarizes datasets previously published and not included in the data release specific to this report (Thompson and others, 2018).

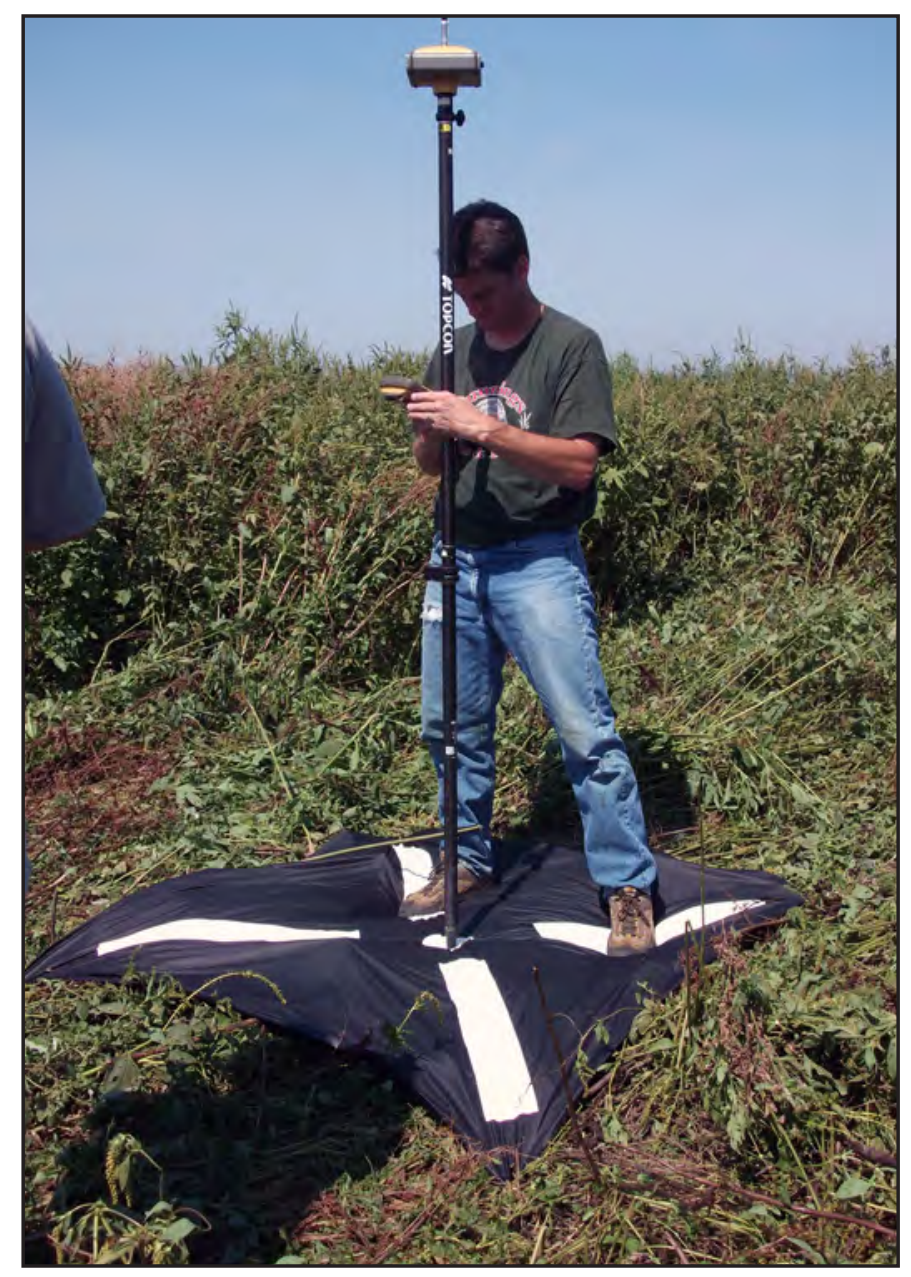

Figure 8. Surveying a target used to georeference images from the drone. Photograph by Kathleen Neitzert.

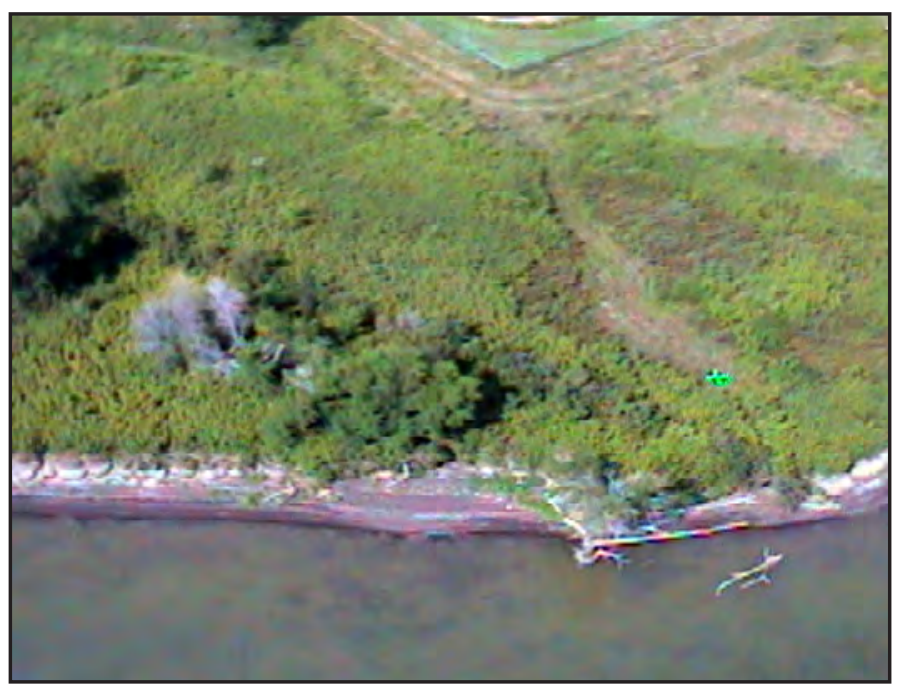

Figure 9. A still capture from the drone video showing the shoreline near Lower Brule, South Dakota, and a target used in georeferencing (green cross in lower-right of image). 


\section{Reservoir Elevation Changes}

Water-level fluctuations of Lake Sharpe contribute to the number of wet-dry cycles experienced by the soils at the shoreline or bank and likely are an important factor in erosional processes. Reservoir surface elevation is recorded at Big Bend Dam by the USACE. Data typically are recorded hourly, but summary reports are available in daily, monthly, and annual formats. The reservoir elevations recorded at the upstream side of Big Bend Dam may tend to show more variations than would be evident 6 miles upstream near Lower Brule because of attenuation; however, reservoir elevation data are not available at Lower Brule. The elevation of Lake Sharpe fluctuates in cycles of multiple scales of time; however, the lake elevation most often varies between 1,420 feet above mean sea level (the base flood-control elevation) and 1,422 feet (the maximum normal operating pool elevation; USACE, 1998). Daily mean reservoir elevation data (USACE, 2014a) are presented in figure 10. At this scale, a weekly cycle is visible. The typical weekly variation begins with a peak on Sunday, followed by declining elevations through Friday, and then a rapid increase over the weekend. During times of the year when increased air conditioning use results in increased power demands, hourly data (USACE, 2014b) can show a similar (though less distinct) cycle repeating over a daily time step (fig. 11). Reservoir levels drop rapidly when releases driven by air conditioning-related power demands are typically greatest during the hottest part of mid-day. Reservoir levels then increase during the overnight hours when energy demands are lower.

\section{Stratification and Soil Studies}

Based on "Areal Geology of the Lower Brule Quadrangle" (Petsch and Curtiss, 1949), the soils present under the current location of the reservoir are predominantly terrace alluvium from the Pleistocene Epoch and consist of sand and silt. The soils at the top in the Big Bend area are predominantly outwash deposited during the Pleistocene Epoch. Outwash is a glaciofluvial deposit made up of sand and gravel usually covered by a layer of loess or silt. A third soil type present in the Big Bend area is the Gregory Member of Pierre Shale from the Upper Cretaceous-age. The Gregory Member consists of brown to brownish-gray clay and numerous brown fossiliferous concretions and impure light-gray chalk.

More detailed maps of Quaternary-age soils were developed by the Natural Resources Conservation Service in the Soil Survey Geographic (SSURGO) database (U.S. Department of Agriculture, 2017). The SSURGO data for Lyman County indicates that the dominant soil type along the southern part of the shoreline in the 7-mile reach is Bullcreek clay (fig. 12). Other soil types predominantly bordering the shoreline of the 7-mile reach include Fairlo silt loam and Carter silt loam.

Soil erodibility is related to many factors but is quantified sometimes using the soil erodibility factor $(K)$ (Institute of Water Research, 2002). The $K$ reflects not only how susceptible a soil is to erosion, but also the water runoff characteristics of the soil. Soils high in clay content are more cohesive and resistant to erosion, and have a low $K$. Sandy soils with a coarse texture are not cohesive, but have a low $K$

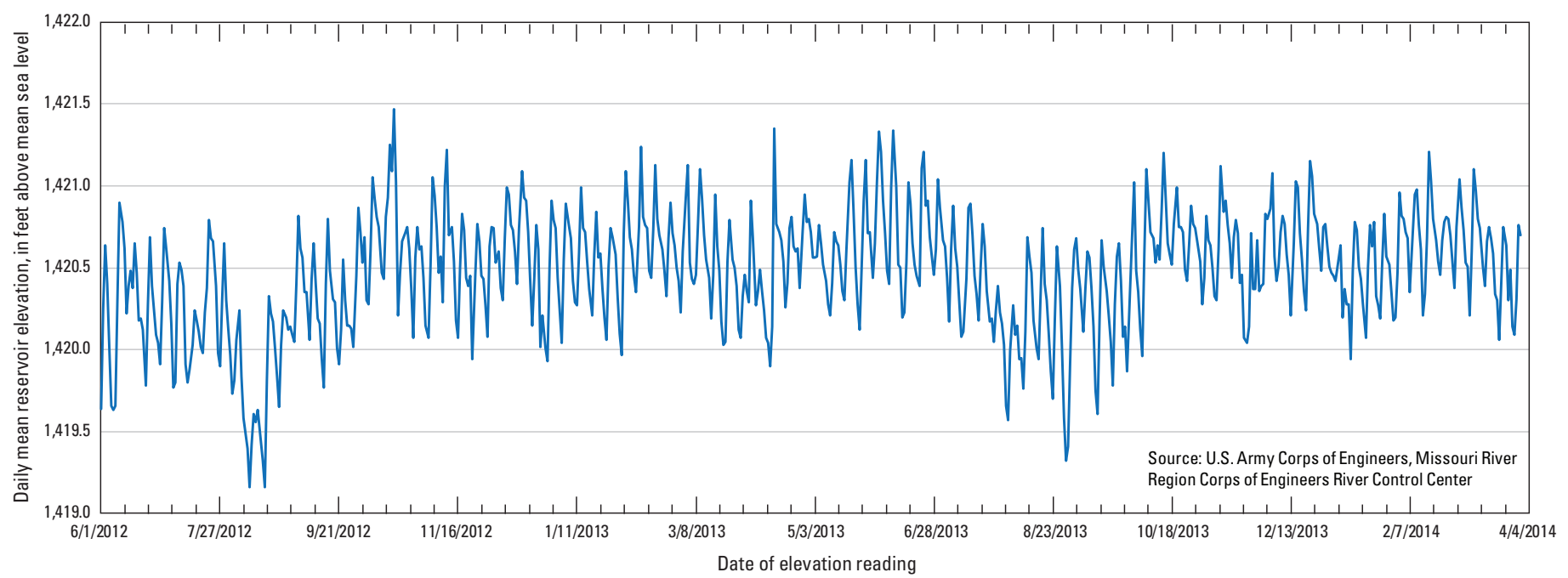

Figure 10. Daily mean reservoir elevation data for June 1, 2012, through April 4, 2014, on Lake Sharpe, South Dakota. 


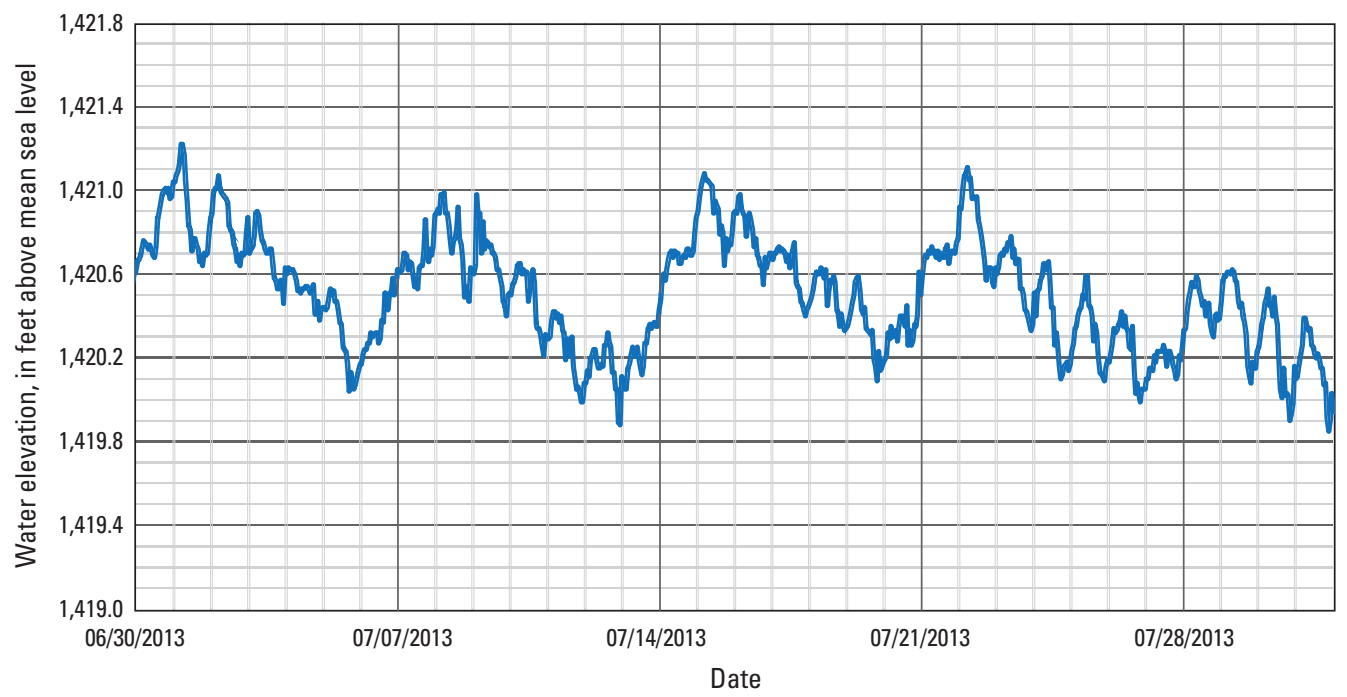

Figure 11. Hourly reservoir water elevation data for July 2013 on Lake Sharpe, South Dakota.

because runoff also is low. Soils with a high silt content are the most erodible and have a high $K$. This high $K$ is because soil particles are easily detached, and the tendency to form a crust results in a high runoff rate (Institute of Water Research, 2002); thus, the silty soils in figure 12 can be expected to erode more easily than the clay soils.

\section{Weather Factors}

Weather within the study area affects the erosion rate (Ritter, 2012). When temperatures drop below freezing for extended periods, soil at and near the land surface freezes, as does the water in the reservoir. Wind speed and direction can affect soil directly through drying and wind erosion, and indirectly through waves. Wave action may directly erode soils at the shore and bank, and the spray from crashing waves may increase the number of wet-dry cycles experienced by a soil nearshore.

\section{Air Temperature}

Air temperature can potentially affect erosion rates by freezing water (Ritter, 2012). Water freezing in the pore spaces of a soil may help soil maintain its structure and resist erosion, at least temporarily. Frozen pore water also may suspend erosion by limiting the number of wet-dry cycles experienced by a soil near the water's edge. Although it may take an extended cold snap to cool the reservoir enough to form ice cover, ice may form much earlier where waves splash against frozen bank soil. During such times, the bank may become somewhat armored by a thick layer of ice (fig. 13). Conversely, when weather warms and ice on the reservoir begins to break up, large sheets of ice can be driven into the shoreline by the wind. If the ice is thick enough, it may scour shoreline soils or push low banks landward, forming an ice heave (fig. 14).
Although a long-term temperature dataset is not available for Lower Brule, extensive data are available for two weather stations near the study area, at Gann Valley, S. Dak., and Kennebec, S. Dak. (fig. 15). Menne and others (2015) developed online daily, monthly, and annual statistics for many weather stations in South Dakota. Average daily temperature data for Kennebec from 1893 to 2014 (fig. 16) and for Gann Valley from 1897 to 2009 (fig. 17) were plotted by day of the year (Julian day). Average daily temperature at both sites tended to be below freezing from mid-November (about Julian day 320) through mid-February (about Julian day 45); however, during some years, winter temperatures remained warm enough that ice formation on the reservoir was limited to very shallow areas near shore.

\section{Wind}

Wind speed relative to water, wind duration, and the distance of water over which the wind blows unobstructed (fetch) all contribute to wave generation in shallow water (USACE, 1954). The LBST worked with a contractor to collect wind data in order to explore the feasibility of wind power generation on the reservation (LBST, 2007). Wind speed data at varying heights above ground were collected at Big Bend Dam and near West Brule (fig. 15) for January 1, 2001, through July 31, 2002. The data were averaged by hourly time steps throughout each month. This helps to quantify the magnitude of sustained winds, rather than peak wind speeds that may be present during shorter periods. Wind speed data at the 98.4-foot height on the tower near West Brule indicated that mean hourly wind speeds vary somewhat throughout the year but averaged 13.3 miles per hour during the 2001-2002 data-collection period (LBST, 2007). Wind direction data are collected by the USACE at the powerhouse on Big Bend Dam (Michael Swenson, USACE, written 


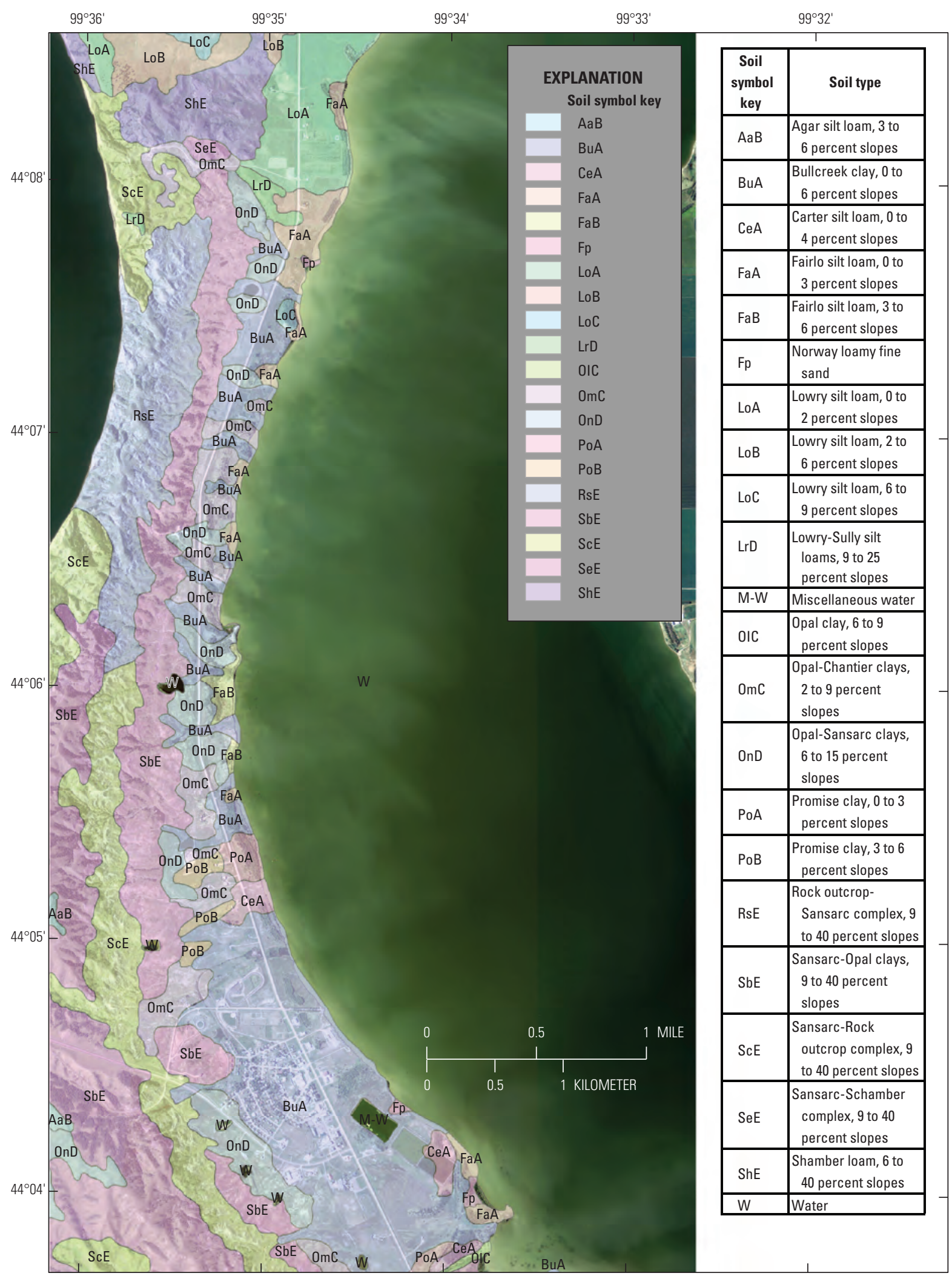

Map image is the intellectual property of Esri and is used herein under license. Copyright (c) 2017 Esri and its licensors. All rights reserved.

Universal Transverse Mercator, Zone 14 North North American Datum of 1983

Figure 12. Soil types in the 7-mile reach of Lake Sharpe near Lower Brule, South Dakota (U.S. Department of Agriculture, 2017). 


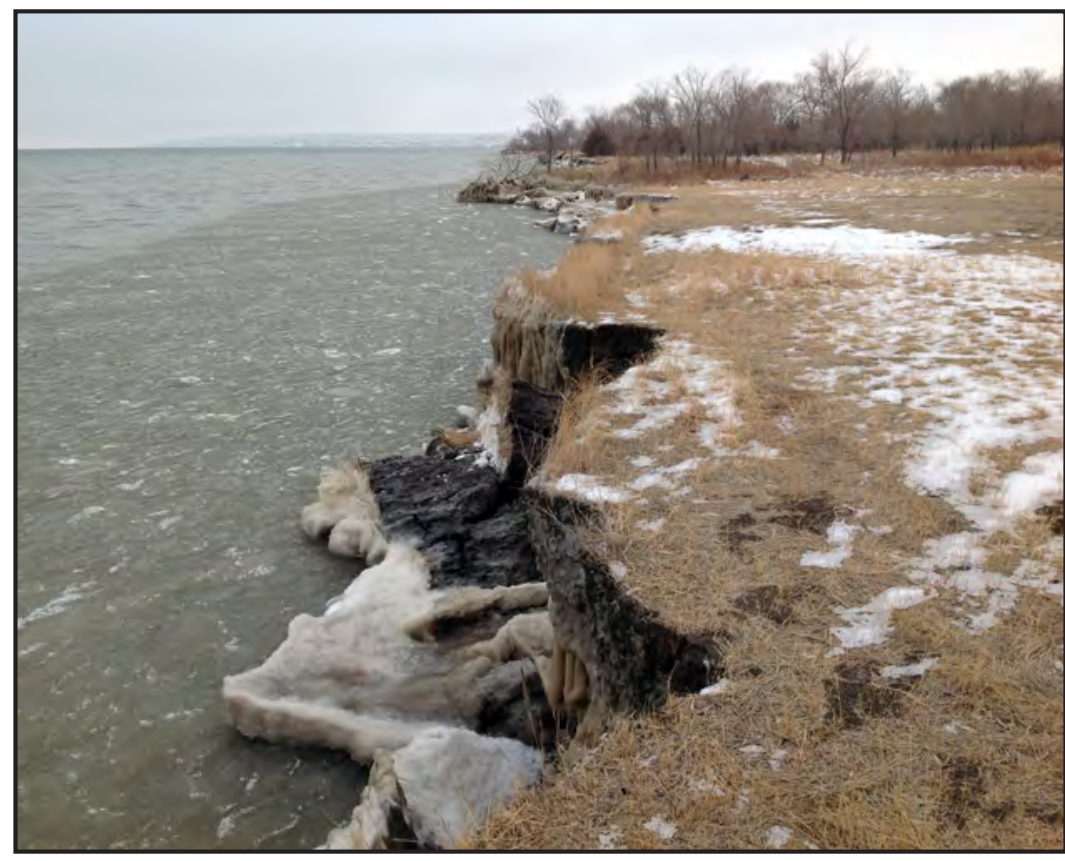

Figure 13. Ice build-up caused by wave action on Lake Sharpe near Lower Brule, South Dakota. Photograph by Kathleen Neitzert.

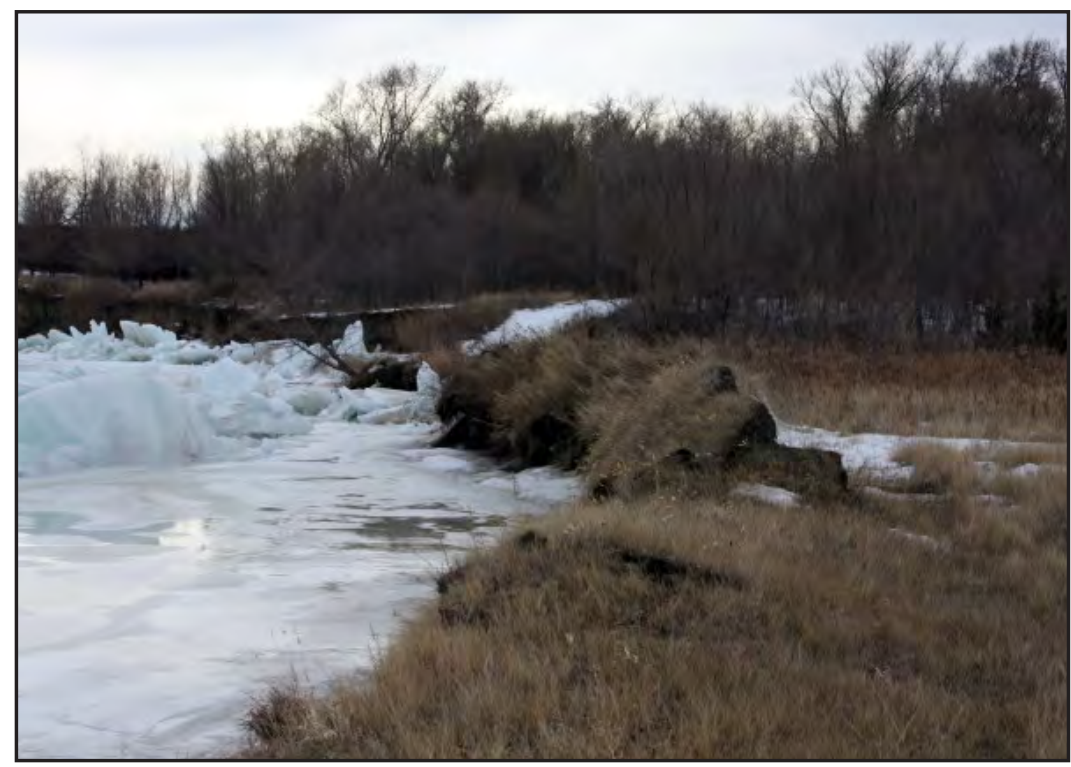

Figure 14. Mounded soils caused by ice heave at Lake Sharpe near Lower Brule, South Dakota. Photograph by George Honeywell, Environmental Protection Office, Lower Brule Sioux Tribe.

commun., 2014) downstream from Lower Brule (fig. 15). Hourly wind direction data from 2013 (fig. 18) shows wind direction is most frequently from north-northwest (320 to 360 degrees) and south-southeast (120 to 180 degrees).

Given the directions of prevailing winds and the location of the 7-mile stretch near Lower Brule on a mainly north-south segment of reservoir, it is not uncommon that sustained winds from the south-southeast will have several miles of fetch in which to build large waves. This was evident during field visits. The same is true (to a lesser degree) for other shoreline reaches oriented primarily east-west upstream from the Big Bend area on the reservation.

\section{Drone Flights}

The links to a page featuring the drone flights to monitor shoreline erosion, a photo gallery, and a poster are available in the appendix. A series of georeferenced still images of the shoreline of the 7-mile reach have been spliced together for use as a base map in ArcGIS software (Esri, 2015) and are available as a companion product within the data release for this study (Thompson and others, 2018). This base map is described in the appendix.

\section{Shoreline Erosion Along Lake Sharpe}

The distance between the digitized 1966 shoreline and shorelines from each of the other imagery dates, measured along the previously described evaluation lines, is given in table 2 . Cumulative change of shoreline based on map and imagery analysis from 1966 to 2010 ranged from about -224 feet (deposition) to 770 feet (erosion). The difference in eroded distance between adjacent imagery dates (table 3 ) represents the amount of erosion between imagery time steps. To account for the different number of years between imagery dates, it also is helpful to view the data as an average annual erosion rate for each of the imagery time steps (table 4). Most evaluation lines have positive erosion rates, but some lines show little erosion or even deposition (negative erosion). Evaluation line 1 was in a low-lying area adjacent to a small ephemeral tributary. This location initially eroded between 1966 and 1991, but a sand and gravel beach was deposited in this area in subsequent years, 1991-2010. Evaluation line 4 had a small amount of initial deposition (1966-91), followed by very gradual erosion (1991-2010, except for some deposition in 2005-2006). This increase in erosion may have been because of the placement of concrete rubble rip-rap on a short reach of shoreline upstream from evaluation line 4. Similarly, evaluation line 17 had an initial rapid deposition (1966-91) and was relatively stable afterwards (1991-2010). A short reach of shoreline downstream from evaluation line 17 had concrete rubble placed as 


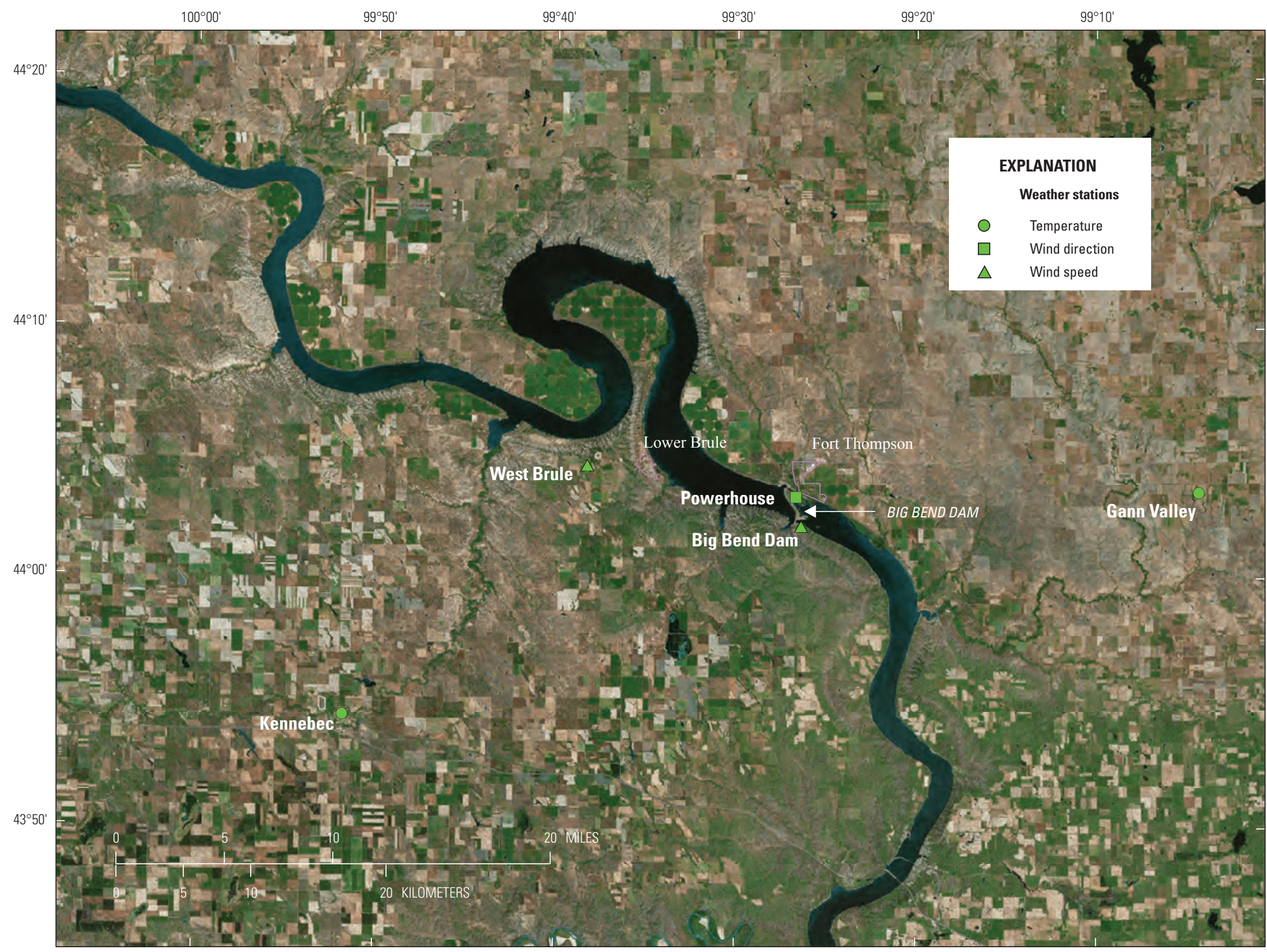

Map image is the intellectual property of Esri and is used

herein under license. Copyright (c) 2017 Esri and its

licensors. All rights reserved.

Universal Transverse Mercator, Zone 14 North

North American Datum of 1983

Figure 15. Locations of weather stations near Lower Brule, South Dakota. 


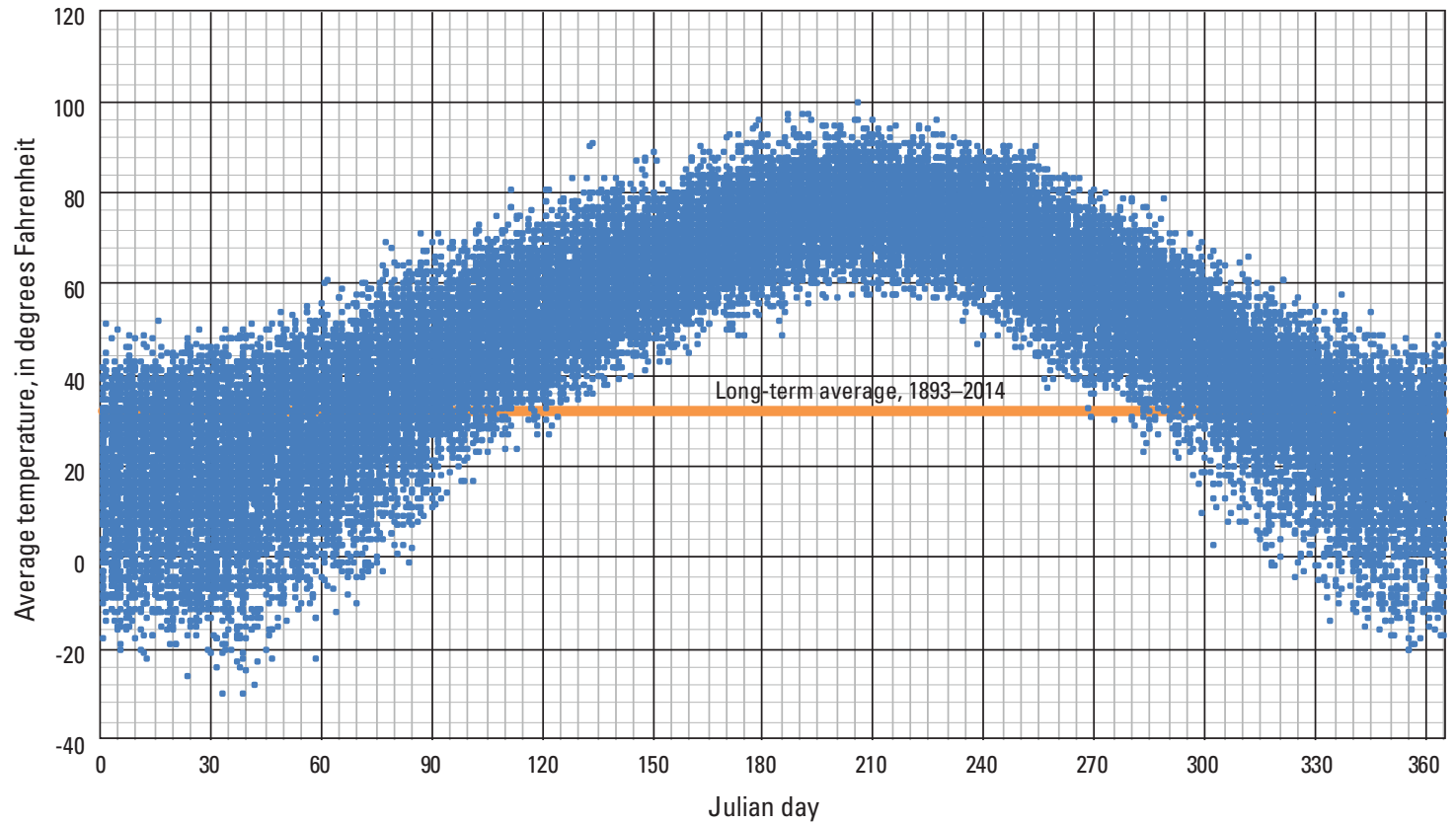

Figure 16. Average daily temperature from the Kennebec, South Dakota, weather station by Julian day of the year, 1893 to 2014.

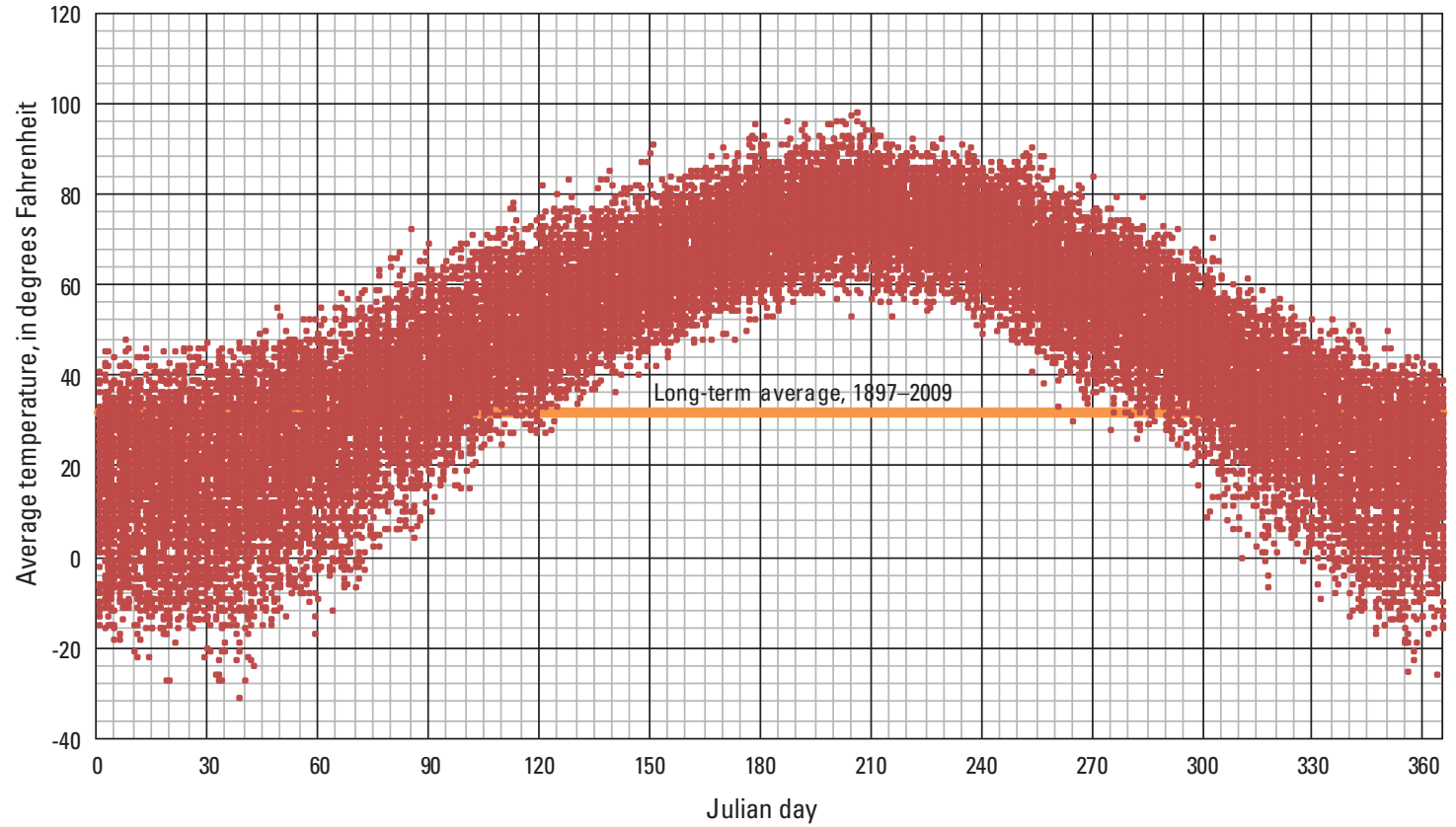

Figure 17. Average daily temperature from the Gann Valley, South Dakota, weather station by Julian day of the year, 1897 to 2009. 


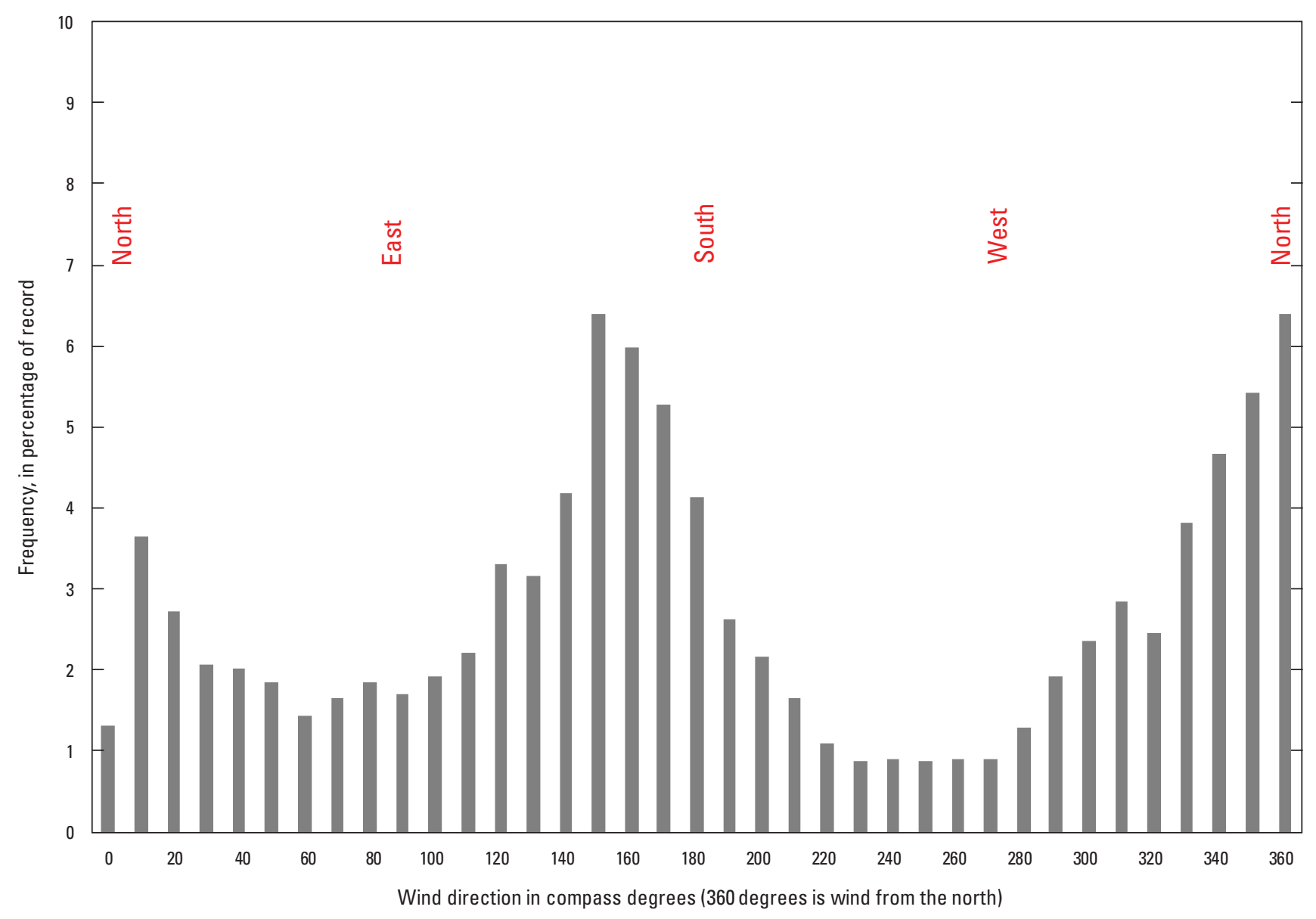

Figure 18. Wind direction at Big Bend Dam, South Dakota, January 1 through December 31, 2013, based on hourly record.

rip-rap, which likely helped to stabilize the area. Evaluation line 21 was immediately adjacent to a small inlet in the 1966 shoreline. This area also initially had some deposition (196691) but underwent erosion from 2005 to 2010 . A reach of shoreline extending roughly from evaluation line 6 to midway between 8 and 9 had fieldstone rip-rap placed in 2010, although this was done sometime after the imagery date and did not affect the measurements in this analysis.

Average annual erosion rates from image analysis varied by evaluation line and period. Average annual erosion rates for the overall period of 1966-2010 ranged from -5.1 feet per year (deposition) to 17.5 feet per year (erosion) (table 4) and were greatest near evaluation line 2 , which is near the sewage lagoons (fig. 4). A comparison of average annual rates between the analysis period (1966-2010) and the most recent several years (2004-10) also is included in table 4 . The recent annual average change ranged from -5.7 feet (deposition) to 13.3 feet (erosion). Recent annual average rates generally are less than or close to the annual average rate for the analysis period (table 4). This closeness of rates may indicate that while the erosion rate was stable or slightly decreasing in some areas, rates remain high enough in other areas (such as at evaluation lines 2 and 3 [fig. 3] near the sewage lagoons, or line 6 near the playground site [fig. 4] at a recreational vehicle park) where infrastructure is still at risk. Annual average erosion rates for 1966-2010 (table 4) were 10 feet per year or greater for 12 of the 33 evaluation lines.

Apart from the evaluation lines with deposition described above, a large amount of erosion was determined from map and imagery analysis during 1966-91 (fig. 2; table 2). This 25-year period represents the longest period between the imagery dates evaluated. During the 2004-2005 and 2005-2006 imagery time steps, many evaluation lines have very small or even negative (deposition) erosion values (table 3). This could be because of the image georeferencing errors described previously or because of different reservoir stages on the imagery dates. The location of the edge of water (shoreline) digitized from the image will be dependent on the reservoir elevation at the time the imagery was collected. In addition to elevation changes associated with actual changes in stored water, reservoir elevation also can be affected greatly by high winds, resulting in localized "pile-up" of water on the downwind shore from wave action. A stacked bar graph can be used to help visualize how erosion compares among evaluation lines for a given image time step (fig. 19). As expected, the changes in shoreline during the 1- and 2-year 
Table 2. Cumulative erosion by evaluation line used in map and imagery analysis for the 7-mile reach on Lake Sharpe near Lower Brule, South Dakota.

[Positive values indicate erosion and negative values indicate deposition; shaded cells represent small changes that may be within georeferencing error bands]

\begin{tabular}{|c|c|c|c|c|c|c|c|}
\hline \multirow{2}{*}{$\begin{array}{l}\text { Evaluation } \\
\text { line } \\
\text { (fig. 3) }\end{array}$} & \multicolumn{5}{|c|}{ Cumulative change in shoreline, in feet } & \multirow{2}{*}{$\begin{array}{c}1966-2010 \\
\text { cumulative } \\
\text { change, } \\
\text { in feet }\end{array}$} & \multirow{2}{*}{$\begin{array}{c}\text { Recent (2004-10) } \\
\text { cumulative } \\
\text { change, } \\
\text { in feet }\end{array}$} \\
\hline & 1966-91 & 1966-2004 & 1966-2005 & 1966-2006 & $1966-2008$ & & \\
\hline 1 & 80 & 19 & 5 & 1 & -5 & -15 & -34 \\
\hline 2 & 587 & 690 & 700 & 713 & 743 & 770 & 80 \\
\hline 3 & 345 & 413 & 417 & 425 & 455 & 467 & 54 \\
\hline 4 & -11 & -8 & -3 & -6 & 2 & 6 & 14 \\
\hline 5 & 426 & 540 & 540 & 547 & 567 & 576 & 36 \\
\hline 6 & 242 & 309 & 309 & 313 & 338 & 345 & 36 \\
\hline 7 & 300 & 396 & 401 & 395 & 420 & 441 & 45 \\
\hline 8 & 183 & 260 & 270 & 279 & 289 & 297 & 37 \\
\hline 9 & 296 & 388 & 400 & 400 & 415 & 434 & 46 \\
\hline 10 & 8 & 49 & 49 & 57 & 67 & 77 & 28 \\
\hline 11 & 263 & 330 & 320 & 336 & 340 & 348 & 18 \\
\hline 12 & 127 & 175 & 169 & 175 & 184 & 192 & 17 \\
\hline 13 & 268 & 284 & 278 & 285 & 284 & 294 & 10 \\
\hline 14 & 386 & 430 & 429 & 434 & 442 & 443 & 13 \\
\hline 15 & 209 & 271 & 263 & 268 & 274 & 281 & 10 \\
\hline 16 & 332 & 388 & 376 & 381 & 380 & 401 & 13 \\
\hline 17 & -224 & -224 & -224 & -221 & -223 & -224 & 0 \\
\hline 18 & 392 & 419 & 415 & 421 & 427 & 439 & 20 \\
\hline 19 & 409 & 458 & 461 & 466 & 469 & 486 & 28 \\
\hline 20 & 343 & 479 & 486 & 505 & 525 & 547 & 68 \\
\hline 21 & -50 & 11 & 0 & 6 & 17 & 35 & 24 \\
\hline 22 & 451 & 516 & 515 & 525 & 537 & 540 & 24 \\
\hline 23 & 338 & 482 & 488 & 492 & 511 & 530 & 48 \\
\hline 24 & 351 & 404 & 407 & 411 & 431 & 439 & 35 \\
\hline 25 & 290 & 361 & 361 & 364 & 383 & 389 & 28 \\
\hline 26 & 133 & 132 & 119 & 122 & 128 & 132 & 0 \\
\hline 27 & 286 & 380 & 372 & 378 & 381 & 384 & 4 \\
\hline 28 & 194 & 270 & 258 & 270 & 277 & 258 & -12 \\
\hline 29 & 157 & 221 & 224 & 225 & 244 & 258 & 37 \\
\hline 30 & 371 & 443 & 438 & 438 & 451 & 463 & 20 \\
\hline 31 & 246 & 316 & 314 & 320 & 328 & 328 & 12 \\
\hline 32 & 212 & 285 & 285 & 287 & 293 & 295 & 10 \\
\hline 33 & 162 & 169 & 169 & 172 & 178 & 191 & 22 \\
\hline
\end{tabular}


Table 3. Average annual erosion from map and imagery analysis for Lake Sharpe near Lower Brule, South Dakota.

[Positive values indicate erosion, and negative values indicate deposition]

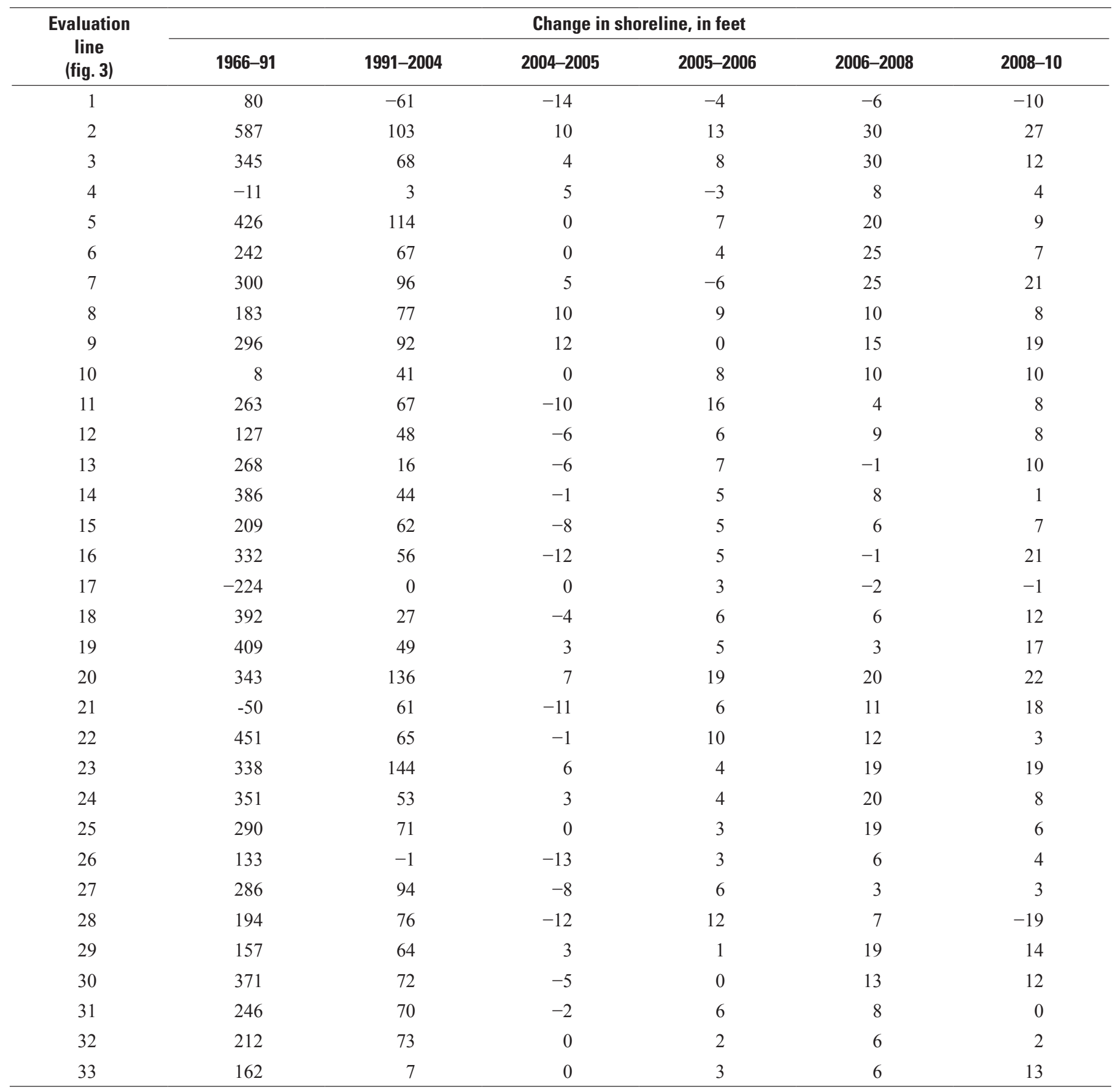


Table 4. Annual erosion at three shoreline locations from real-time kinematic bank surveys on Lake Sharpe near Lower Brule, South Dakota.

[Positive values indicate erosion, and negative values indicate deposition]

\begin{tabular}{|c|c|c|c|c|c|c|c|c|}
\hline \multirow{2}{*}{$\begin{array}{l}\text { Evaluation } \\
\text { line } \\
\text { (fig. 3) }\end{array}$} & \multicolumn{6}{|c|}{ Average annual change in shoreline by time step, in feet } & \multirow{2}{*}{$\begin{array}{l}\text { 1966-2010 } \\
\text { annual } \\
\text { average change, } \\
\text { in feet }\end{array}$} & \multirow{2}{*}{$\begin{array}{l}\text { Recent (2004-10) } \\
\text { annual average } \\
\text { change, } \\
\text { in feet }\end{array}$} \\
\hline & $1966-91$ & 1991-2004 & 2004-2005 & 2005-2006 & 2006-2008 & 2008-10 & & \\
\hline 1 & 3.2 & -4.7 & -14.0 & -4.0 & -3.0 & -5.0 & -0.3 & -5.7 \\
\hline 2 & 23.5 & 7.9 & 10.0 & 13.0 & 15.0 & 13.5 & 17.5 & 13.3 \\
\hline 5 & 17.0 & 8.8 & 0.0 & 7.0 & 10.0 & 4.5 & 13.1 & 6.0 \\
\hline 6 & 9.7 & 5.2 & 0.0 & 4.0 & 12.5 & 3.5 & 7.8 & 6.0 \\
\hline 7 & 12.0 & 7.4 & 5.0 & -6.0 & 12.5 & 10.5 & 10.0 & 7.5 \\
\hline 8 & 7.3 & 5.9 & 10.0 & 9.0 & 5.0 & 4.0 & 6.8 & 6.2 \\
\hline 12 & 5.1 & 3.7 & -6.0 & 6.0 & 4.5 & 4.0 & 4.4 & 2.8 \\
\hline 13 & 10.7 & 1.2 & -6.0 & 7.0 & -0.5 & 5.0 & 6.7 & 1.7 \\
\hline 14 & 15.4 & 3.4 & -1.0 & 5.0 & 4.0 & 0.5 & 10.1 & 2.2 \\
\hline 15 & 8.4 & 4.8 & -8.0 & 5.0 & 3.0 & 3.5 & 6.4 & 1.7 \\
\hline 16 & 13.3 & 4.3 & -12.0 & 5.0 & -0.5 & 10.5 & 9.1 & 2.2 \\
\hline 17 & -9.0 & 0.0 & 0.0 & 3.0 & -1.0 & -0.5 & -5.1 & 0.0 \\
\hline 18 & 15.7 & 2.1 & -4.0 & 6.0 & 3.0 & 6.0 & 10.0 & 3.3 \\
\hline 19 & 16.4 & 3.8 & 3.0 & 5.0 & 1.5 & 8.5 & 11.0 & 4.7 \\
\hline 26 & 5.3 & -0.1 & -13.0 & 3.0 & 3.0 & 2.0 & 3.0 & 0.0 \\
\hline 27 & 11.4 & 7.2 & -8.0 & 6.0 & 1.5 & 1.5 & 8.7 & 0.7 \\
\hline 28 & 7.8 & 5.8 & -12.0 & 12.0 & 3.5 & -9.5 & 5.9 & -2.0 \\
\hline 29 & 6.3 & 4.9 & 3.0 & 1.0 & 9.5 & 7.0 & 5.9 & 6.2 \\
\hline 30 & 14.8 & 5.5 & -5.0 & 0.0 & 6.5 & 6.0 & 10.5 & 3.3 \\
\hline 31 & 9.8 & 5.4 & -2.0 & 6.0 & 4.0 & 0.0 & 7.5 & 2.0 \\
\hline 32 & 8.5 & 5.6 & 0.0 & 2.0 & 3.0 & 1.0 & 6.7 & 1.7 \\
\hline 33 & 6.5 & 0.5 & 0.0 & 3.0 & 3.0 & 6.5 & 4.3 & 3.7 \\
\hline
\end{tabular}




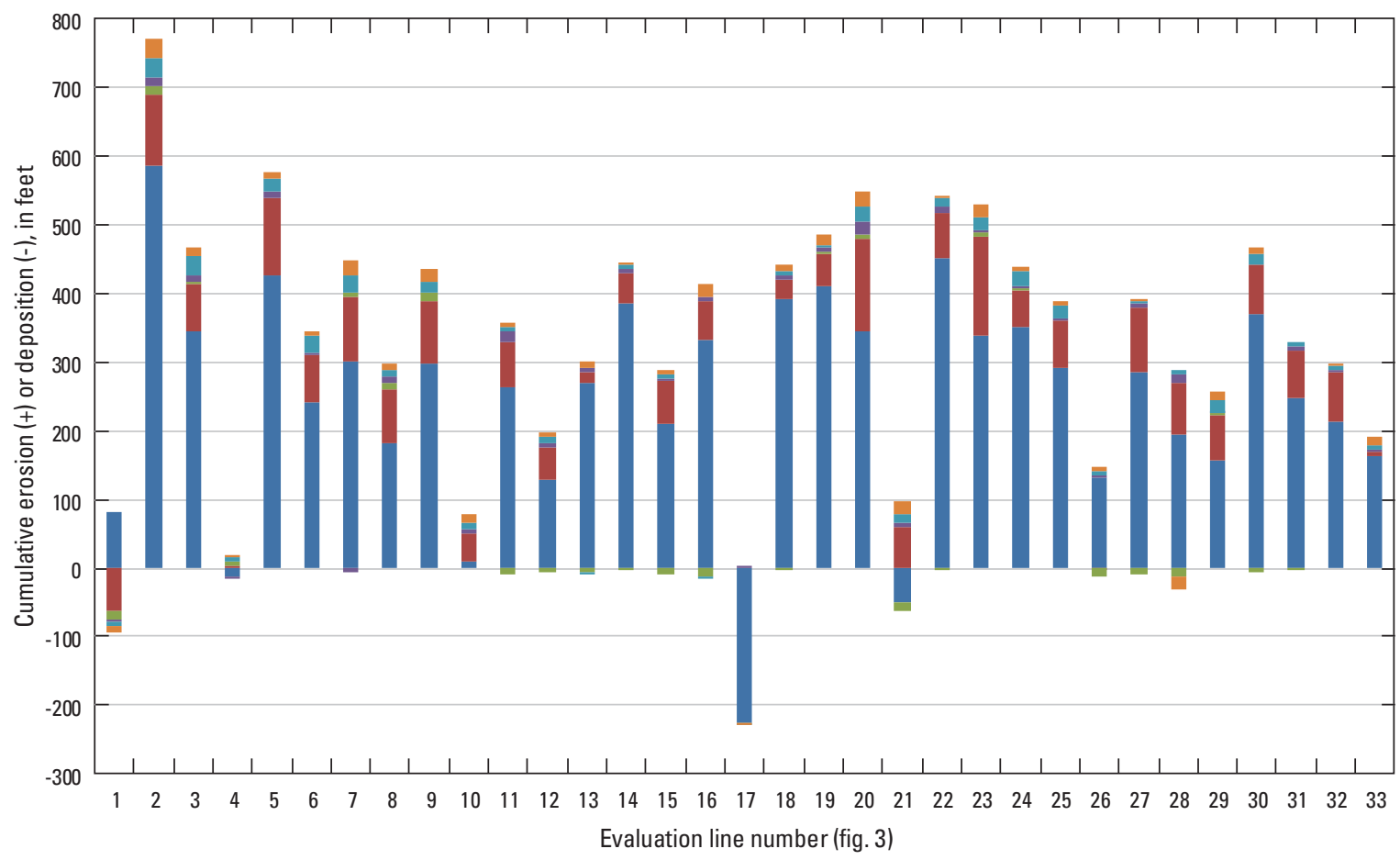

Figure 19. Cumulative erosion by time step by evaluation line from map and imagery analysis for Lake Sharpe near Lower Brule, South Dakota.

imagery periods are generally much smaller than for the first two periods. Although the image analysis methodology may have some uncertainty because of image georeferencing, this analysis allows erosion rates to be calculated much further back than GNSS surveying data were available.

Time-lapse videos of erosion provide a unique way to understand erosional processes. It is possible to see when erosion happens and sometimes identify factors that may have contributed to the erosion. For example, sometimes a large block of bank soil will collapse, whereas at other times, multiple narrow slivers drop off the bank, resulting in a more uniform erosional pattern. Possible influences of wave action also can be seen. Depending upon the size of the waves, they may undercut the bank and cause collapse, or repeated splashing from waves may moisten banks and allow the soil to be washed away. A description of the time-lapse videos available in Thompson and others (2018) is provided in the appendix.

At the lagoon site camera location 1 (Lagoon1.mp4 video in Thompson and others [2018]), the erosion was fairly uniform throughout the field of view. Because of the vegetation on the bank, it was somewhat difficult to track, but it was possible to see that the bank advances landward to the small elm tree seedling near the center of the frame. After the Lagoon site camera was relocated to location 2 (Lagoon2.mp4 video in Thompson and others [2018]), erosion was much easier to see. A series of wooden stakes painted fluorescent orange were placed to provide visible reference points as the bank advances landward. The images at the playground site (Playground.mp4 video in Thompson and others [2018]) provide a good view of several factors, which were described in the "Reservoir Elevation Changes" and "Weather Factors" sections of this report. The images show how differing reservoir elevations placed the water surface at the toe of the bank or several feet away from it, how wave action during warmer parts of the year could splash and wet the bank making it easier to wash away, and how a bank could be armored by ice formations.

Bank surveys completed with RTK provided an accurate way to track shoreline erosion. Short-term annual (November 2011 to November 2012) erosion rates measured in the 7-mile reach ranged from about 0 to 31.7 feet for the 7 -mile reach, 0 to 18.3 feet for the Island reach, and 0 to 11.4 feet for the Fort George reach (table 5). The long-term average annual erosion rates calculated from image analysis (table 4) fit within the range of values measured using RTK for short-term annual erosion.

Table 5. Incremental erosion between imagery dates by evaluation line used in map and imagery analysis for Lake Sharpe near Lower Brule, South Dakota.

[NA, not available]

\begin{tabular}{lccccc}
\hline \multirow{2}{*}{ Reach } & \multicolumn{2}{c}{ November 2010-November 2011 } & & \multicolumn{2}{c}{ November 2011-November 2012 } \\
\cline { 2 - 3 } \cline { 5 - 6 } & $\begin{array}{c}\text { Maximum, } \\
\text { in feet }\end{array}$ & $\begin{array}{c}\text { Minimum, } \\
\text { in feet }\end{array}$ & & $\begin{array}{c}\text { Maximum, } \\
\text { in feet }\end{array}$ & $\begin{array}{c}\text { Minimum, } \\
\text { in feet }\end{array}$ \\
\hline Fort George & NA & NA & & 11.4 & 0 \\
Island & NA & NA & & 18.3 & 0 \\
7-mile & 10.0 & 0 & & 31.7 & 0 \\
\hline
\end{tabular}


Estimates of volumetric erosion rates from lidar analysis were not published because only limited comparisons could be made for the exposed parts of the banks; however, the equipment is well suited for the task and could be used to successfully collect these types of data if weather conditions were favorable or if modifications to the field methods could be made. Surveying from the ice provided a stable and relatively safe place to set up the tripod, but the snow that often accompanies winter surveys obscured most of the bank area near the playground site. If weather conditions had allowed for good ice formation without any accompanying snow, bank visibility would have been improved. If the lidar scans could have been completed during warmer weather from a tripod placed in shallow water on a day with no wave action, the effects of snow cover might also have been avoided. Alternately, with additional equipment such as pitch and roll sensors and an inertial measurement unit, it also may have been possible to collect tripod-based lidar data from a moving boat. This also would have made it easier to collect lidar data on longer reaches of shoreline bank and could have helped ensure that calculated volumetric erosion rates were more representative than if data were only collected at smaller localized sites. If soil sampling had been completed in conjunction with lidar surveys, it also may have been possible to develop a more quantitative erosion risk based on soil type. These topics could be revisited in future studies to verify and enhance findings from this study.

\section{Erosion Countermeasures}

Existing erosion countermeasures (fig. 20) have been effective to varying degrees. Fieldstone rip-rap was placed along the shoreline in 2010 (Brian Molyneaux, LBST, written commun., 2018) starting near the Lower Brule Rural Water System and extending upstream (north) for about 2,200 feet. This fieldstone rip-rap and a similar placement in the Fort George (fig. 1) reach in 2005 (Brian Molyneaux, LBST, written commun., 2018) seem to have stabilized the shoreline. The contrast between rip-rapped and non-rip-rapped shoreline is especially evident at the southern tip of the rip-rap placed near the Lower Brule Rural Water System (fig. 20, inset B). Bank lines developed from field surveys show erosion advanced rapidly along the unprotected shoreline, whereas the rip-rap maintained a stable land-water interface. Tree strips were established in selected locations parallel to the shoreline north of Lower Brule in the 7-mile reach. An exact planting date is not known, but 1991 digital Orthophoto quadrangle imagery shows areas of tilled ground where the tree strips are now located. Small trees may also have been present at that time, but imagery resolution is not sufficient to show such details. These tree strips seem to have slowed erosion to some degree, once the shoreline eroded back to the edge of the tree strip. For example, shoreline erosion just past the south end of one of the tree strips north of Lower Brule (fig. 20, inset A) advanced faster than in areas where tree roots are present. Ultimately, erosion did continue even among the tree roots, and in some areas several trees toppled into the water as a group, still connected by their intertwined roots. The presence of downed trees in the water near the bank may still offer erosion protection because the branches and roots seem to help reduce wave action at the bank. Concrete rubble was placed along the shoreline in two locations (fig. 20). The concrete rubble was sourced from various site clean-up efforts over the years, rather than as a single placement. Although the rubble often did not cover the bank as completely as the fieldstone rip-rap, it did seem to slow erosion, and in some areas offered enough protection to allow willow trees to establish on the shore.

\section{Effects of Soils}

The wide range in measured erosion within the 7-mile reach could be because of many factors. Differences in soil properties likely are an important determining factor. Some of the greatest erosion amounts in the 7-mile reach near Lower Brule coincide with areas dominated by Bullcreek clay and Fairlo silt loam (plate 1, available for download at https:// doi.org/10.3133/sir20185058 and described in the appendix). Areas in plate 1 undergoing higher erosion rates will have more widely spaced bank lines. Some areas mapped with Fairlo silt loam or Bullcreek clay do not have widely spaced bank lines. In some cases, this could be affected by vegetation or root structure helping to hold the soil together, but bank height and thickness of the mapped soils also could be a factor. The central part of the 7-mile reach has banks 8 or more feet above the water level in some areas. If the thickness of the mapped soils is less than the bank height, an underlying soil type with different properties may be exposed near the water level and may affect erosion rates more than the surface soil. The software used to display plate 1 may contain additional tools that can be used to determine erosion amounts or rates at specific locations. A discussion of these methods is included in the appendix at the end of the report. 


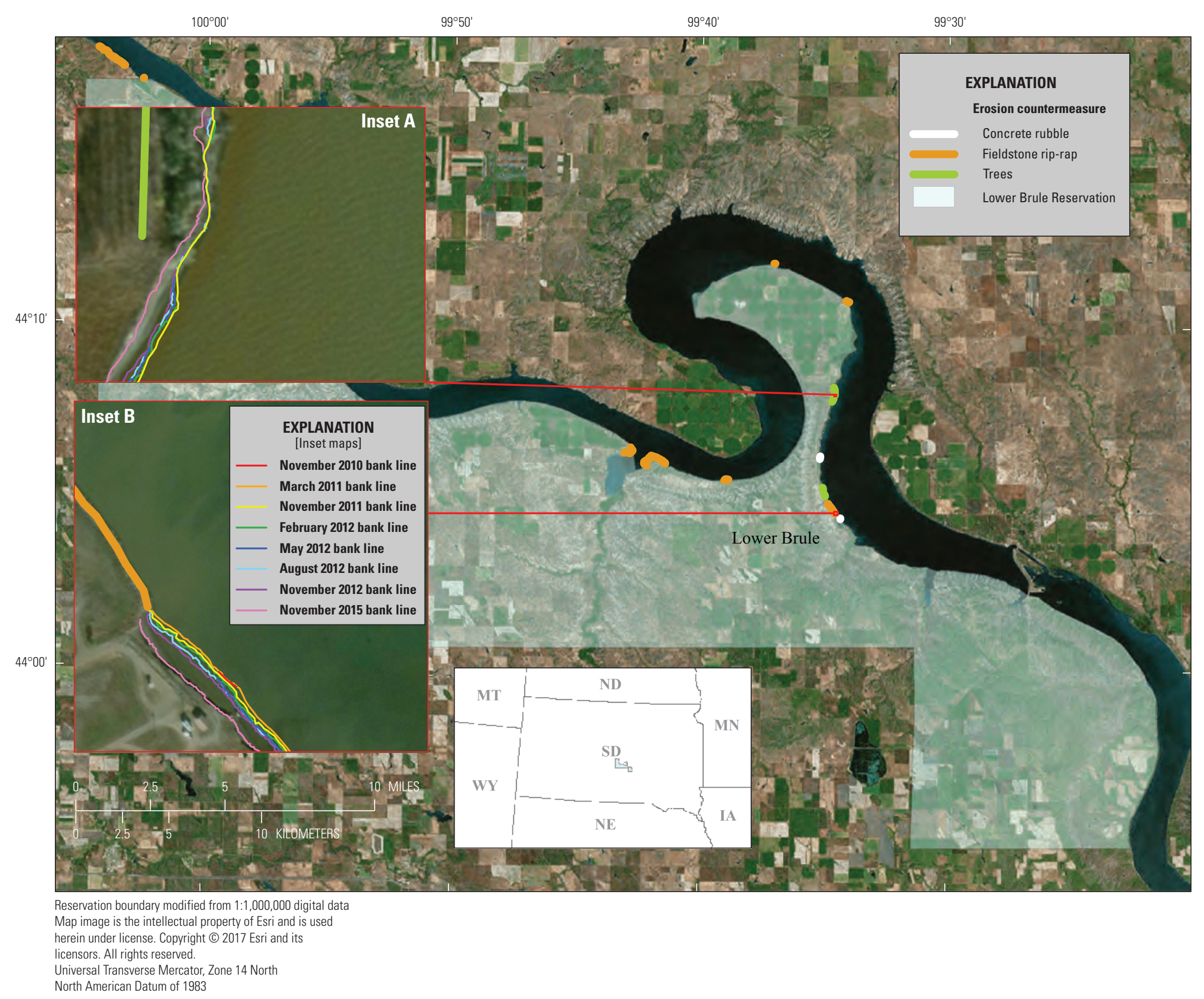

Figure 20. Erosion countermeasures along Lake Sharpe near Lower Brule, South Dakota. 


\section{Summary}

The Lower Brule Reservation in central South Dakota is losing land because of shoreline erosion along Lake Sharpe, a reservoir on the Missouri River. This loss of land area has caused detrimental effects for the Lower Brule Sioux Tribe including losses of cultural sites, recreation access points, wildlife habitat, irrigated cropland, and landmass. To better understand and quantify shoreline erosion, the Lower Brule Sioux Tribe and the U.S. Geological Survey have cooperated on a series of data-collection efforts and study of shoreline erosion along Lake Sharpe. The progression of shoreline erosion near Lower Brule, South Dakota, was tracked by comparing current or recent aerial imagery with existing historical maps. Shoreline trace lines were constructed from different image years and displayed with a shoreline trace from the 1966 U.S. Geological Survey 7.5-minute quadrangle map. A total of 33 evaluation lines were used to identify areas where distance to shoreline was measured. Cumulative change of shoreline from 1966 to 2010 ranged from about -224 feet (deposition) to 770 feet (erosion).

Photographic and location data were collected for this study to understand the processes affecting erosion and estimate erosion rates. The photos were collected only in the 7-mile reach near Lower Brule, but locations of the bank over time were collected at three reaches within the Lower Brule Reservation. Global navigation satellite system equipment was used in real-time kinematic mode to collect bank locations along each of the three reaches. Quarterly, reach-length data collection took place between November 2011 and November 2012. A small, unmanned aerial system, or drone, with an on-board natural-color camera was used to capture digital video along the shoreline of the 7-mile reach.

Water level fluctuations contribute to the number of wet-dry cycles experienced by the soils at the shoreline or bank, and likely are an important factor in erosional processes. The soils present under the current location of the reservoir are predominantly terrace alluvium, consisting of sand and silt. Detailed soils data for Lyman County indicate that the dominant soil type along the southern part of the shoreline in the 7-mile reach is Bullcreek clay. Soil erodibility is related to many factors, but silty soils can be expected to erode more easily than clay soils. Weather within the study area can affect the erosion rate. Air temperature potentially can affect erosion rates by freezing water and soils. Mean hourly wind speeds varied somewhat throughout the year but averaged 13.3 miles per hour. The direction of prevailing winds near Lower Brule indicates that there are several miles of fetch in which to build large waves.

Annual erosion rates calculated or measured throughout this study varied by location. Long-term average annual erosion rates of the 7-mile reach, as calculated by image analysis, ranged from -5.1 feet per year (deposition) to 17.5 feet per year (erosion). Short-term annual erosion rates measured using real-time kinematic surveys ranged from about 0 to 31.7 feet per year for the 7-mile reach. Existing erosion countermeasures have been variably effective. Fieldstone rip-rap seems to have stabilized the shoreline, whereas tree strips paralleling the shoreline seem only to have slowed erosion.

\section{References Cited}

Adobe, 2017, Adobe Photoshop family: Adobe, accessed February 22, 2017, at http://www.adobe.com/products/photoshopfamily.html.

Esri, 2015, ArcGIS for desktop: Esri, software, accessed August 17, 2015, at https://desktop.arcgis.com/en/desktop/.

Ferrell, J.R., 1993, Big dam era-A legislative and institutional history of the Pick-Sloan Missouri Basin Program: Omaha, Nebr., U.S. Army Corps of Engineers, Missouri River Division, accessed September 13, 2017, at http:// www.nwd-mr.usace.army.mil/rce/reports/pdfs/BigDamEra. pdf.

Institute of Water Research, 2002, K factor: Michigan State University, Institute of Water Research web page, accessed August 26, 2016, at http://www.iwr.msu.edu/rusle/kfactor. htm.

Lower Brule Sioux Tribe [LBST], 2007, Final report-Lower Brule Sioux Tribe wind-pumped storage feasibility study project: Lower Brule, S. Dak., Lower Brule Sioux Tribe, accessed December 20, 2017, at https://energy.gov/sites/ prod/files/2016/02/f30/lowerbrule03final_0.pdf.

Menne, M.J., Williams, C.N., Jr., and Vose, R.S., 2015,Longterm daily and monthly climate records from stations across the contiguous United States: National Oceanic and Atmospheric Administration, National Climatic Data Center, United States Historical Climatology Network dataset, accessed February 3, 2016, at http://cdiac.ornl.gov/epubs/ ndp/ushen/ushen.html.

National Geodetic Survey, 2016, OPUS — Online Positioning User Service: National Oceanic and Atmospheric Administration, National Geodetic Survey, accessed January 29, 2016, at https://www.ngs.noaa.gov/OPUS/.

National Park Service, 2015, Lake Sharpe-Big Bend DamBig Bend Dam and reservoir area: Smithsonian, National Park Service web page, accessed August 14, 2015 at http:// www.nps.gov/parkhistory/online_books/smithsonian/lakesharpe/sec2.htm.

Petsch, B.C., and Curtiss, R.E., 1949, Areal geology of the Lower Brule quadrangle: South Dakota Geological Survey, 1 sheet, scale 1:62,500, accessed September 13, 2017, at http://www.sdgs.usd.edu/pubs/pdf/GQ62K-004.pdf. 
Ritter, Jim, 2012, Soil erosion-Causes and effects: Ontario Ministry of Agriculture, Food and Rural Affairs fact sheet, accessed January 8, 2018, at http://www.omafra.gov.on.ca/ english/engineer/facts/12-053.htm.

Rydlund, P.H., Jr., and Densmore, B.K., 2012, Methods of practice and guidelines for using survey-grade global navigation satellite systems (GNSS) to establish vertical datum in the United States Geological Survey: U.S. Geological Survey Techniques and Methods, book 11, chap. D1, 102 p. with appendixes, accessed April 17, 2014, at http://pubs. usgs.gov/tm/11d $1 /$.

South Dakota State Historical Society, 2008, Protecting our past—South Dakota archaeology and historic preservation month: South Dakota State Historical Society, Lower Brule Sioux Tribe, poster, accessed September 13, 2017, at http:// history.sd.gov/preservation/Images/2008poster.pdf.

Thompson, R.F., 2014, Nearshore bathymetric mapping along a 7-mile reach of Lake Sharpe shoreline near Lower Brule, South Dakota, 2013: U.S. Geological Survey Scientific Investigations Map 3307, 2 sheets. [Also available at https:// doi.org/10.3133/sim3307.]

Thompson, R.F., Martinez, A., and Bauer, M.A., 2018, Data to document shoreline erosion at selected locations along Lake Sharpe on the Lower Brule Reservation in South Dakota, 1966-2015: U.S. Geological Survey data release, https:// doi.org/10.5066/F7H130XV.

U.S. Army Corps of Engineers [USACE], 1954, Generation of wind waves over a shallow bottom: U.S. Army Corps of Engineers, Technical Memorandum no. 51, accessed January 20, 2016, at http://www.dtic.mil/dtic/tr/fulltext/ u2/046517.pdf.

U.S. Army Corps of Engineers [USACE], 1998, Missouri River main stem reservoirs - System description and operation: U.S. Army Corps of Engineers, accessed January 15, 2016, at http:/www.nwd-mr.usace.army.mil/rcc/reports/ pdfs/aop98b.pdf.

U.S. Army Corps of Engineers [USACE], 2014a, Missouri River Basin water management information: U.S. Army Corps of Engineers, Missouri River Basin Water Management Division web page, accessed April 22, 2014, at http:// www.nwd-mr.usace.army.mil/rcc/index.html.

U.S. Army Corps of Engineers [USACE], 2014b, Hourly DCP data: U.S. Army Corps of Engineers, Missouri River Basin Water Management Division web page, accessed April 22, 2014, at http://www.nwd-mr.usace.army.mil/rcc/programs/ dcpext.html.
U.S. Army Corps of Engineers [USACE], 2015a, Big Bend Dam \& Lake Sharpe: U.S. Army Corps of Engineers web page, accessed August 14, 2015, at http://www.nwo.usace. army.mil/Missions/DamandLakeProjects/MissouriRiverDams/BigBend.aspx.

U.S. Army Corps of Engineers [USACE], 2015b, Big Bend project statistics: U.S. Army Corps of Engineers web page, accessed August 14, 2015, at http://www.nwo.usace.army. mil/Media/FactSheets/FactSheetArticleView/tabid/2034/ Article/487637/big-bend-project-statistics.aspx.

U.S. Department of Agriculture, 2013, National Agriculture Imagery Program (NAIP) information sheet: U.S. Department of Agriculture, accessed February 16, 2017, at https://www.fsa.usda.gov/Internet/FSA_File/naip_info_ sheet_2013.pdf.

U.S. Department of Agriculture, 2017, Description of SSURGO database: U.S. Department of Agriculture, Natural Resources Conservation Service web page, accessed September 13, 2017, at https:/www.nrcs.usda.gov/wps/por$\mathrm{tal} / \mathrm{nrcs} /$ detail/soils/survey/?cid=nrcs142p2_053627.

U.S. Geological Survey [USGS], 1996a, National Mapping Program technical instructions_-Part 1 general-Standards for digital orthophotos: U.S. Geological Survey, National Mapping Division, accessed February 16, 2017, at https:// nationalmap.gov/standards/pdf/1DOQ1296.PDF.

U.S. Geological Survey [USGS], 1996b, National Mapping Program technical instructions-Part 2 specificationsStandards for digital orthophotos: U.S. Geological Survey, National Mapping Division, accessed February 16, 2017, at https://nationalmap.gov/standards/pdf/2DOQ1296.PDF.

U.S. Geological Survey [USGS], 2015, Digital Orthophoto Quadrangle (DOQs): U.S. Geological Survey, Long Term Archive, accessed April 17, 2018 at https://lta.cr.usgs.gov/ DOQs.

U.S. Geological Survey [USGS], 2017, Published Maps: U.S. Geological Survey, The National Map, accessed April 17, 2018 at https://nationalmap.gov/maps.html. 


\section{Appendix}

A data release containing the individual datasets has been posted to U.S. Geological Survey ScienceBase at https://doi.org/10.5066/F7H130XV (Thompson and others, 2018). On this landing page, links are present that connect to four "Child Items" — one for each of the four categories of datasets in this data release. The headings below identify the individual datasets and associated metadata files that can be downloaded from links on the landing page for each Child Item. 


\section{Shoreline Base Map Generated from Drone Imagery}

The Child Item titled "Aerial imagery base map for the Lake Sharpe shoreline near Lower Brule, South Dakota, captured from an unmanned aerial system, August 2012" links to a page describing this data-collection effort. This page also contains links that can be used to download the metadata file and a zipped folder containing the files required to display a base-map image generated from the drone's video camera in August 2012. The base map was developed by splicing together georeferenced, still images captured as individual frames from the video.

The website of the U.S. Geological Survey's National Unmanned Aircraft Systems Project Office (https://uas.usgs. gov/index.shtml) includes web pages highlighting the drone missions completed for various science research topics. The page featuring the drone flights to monitor shoreline erosion at Lower Brule is at https://uas.usgs.gov/mission/ SD_MissouriRiverBankErosion.shtml. Additional photos are available in a gallery at https:/www.flickr.com/photos/usgs uas_project_office/albums/72157631896233813. A poster highlighting the shoreline erosion flights at Lower Brule is available at https://uas.usgs.gov/postergallery.shtml.

\section{Shoreline Traces in Shapefile Format}

The Child Item titled "Historical shoreline traces of Lake Sharpe near Lower Brule, South Dakota, 1966-2010" links to a page describing the digitizing effort and the resulting dataset. Links on this page can be used to download the metadata file and a zipped folder containing a shapefile of shoreline traces from 1966, 1991, 2004, 2005, 2006, 2008, and 2010. The 1966 shoreline is based on the 1966 U.S. Geological Survey 7.5-minute quadrangle maps, whereas the other dates were available as imagery.

\section{Global Navigation Satellite System Survey Data in Shapefile Format}

The Child Item titled "Surveyed bank locations of the Lake Sharpe shoreline at selected locations on the Lower Brule Reservation, South Dakota, 2010-15" describes the GNSS surveying effort used to collect shoreline locations over time. This page also contains links to a general metadata file and links for four different zipped folders. The zipped folders contain specific metadata and datasets for the control points used in the surveying efforts, as well as the data collected at each of the three locations: the Fort George reach, the Island reach, and the 7-mile reach. Point shapefiles for the various dates are available for each of the three reaches, and line shapefiles approximating the edge of bank also are available for the 7-mile reach. The datasets within each of the zipped folders are itemized in the following list:
- Control points.zip

- Control points used to survey all three reaches (control_pts.shp)

- Ft_George.zip

- $\quad$ Fort George reach bank points, November 2011 (FG_Nov2011.shp)

- $\quad$ Fort George reach bank points, February 2012 (FG_Feb2012.shp)

- $\quad$ Fort George reach bank points, May 2012 (FG May2012.shp)

- $\quad$ Fort George reach bank points, August 2012 (FG_Aug2012.shp)

- $\quad$ Fort George reach bank points, November 2012 (FG_Nov2012.shp)

- Island.zip

- Island reach bank points, November 2011 (Is Nov2011.shp)

- Island reach bank points, May 2012 (Is May2012.shp)

- Island reach bank points, November 2012 (Is Nov2012.shp)

- 7 mile.zip

- $\quad$ 7-mile reach bank points, November 2010 (sm Nov2010.shp)

- 7-mile reach bank lines, November 2010 (sm Nov2010_bnkln.shp)

- $\quad$ 7-mile reach bank points, March 2011 (sm_ Mar2011.shp)

- 7-mile reach bank lines, March 2011 (sm_ Mar2011_bnkln.shp)

- $\quad$ 7-mile reach bank points, November 2011 (sm Nov2011.shp)

- 7-mile reach bank lines, November 2011 (sm Nov2011_bnkln.shp)

- 7-mile reach bank points, February 2012 (sm Feb2012.shp)

- 7-mile reach bank lines, February 2012 (sm Feb2012_bnkln.shp)

- 7-mile reach bank points, May 2012 (sm May2012.shp) 
- 7-mile reach bank lines, May 2012 (sm May2012_bnkln.shp)

- 7-mile reach bank points, August 2012 (sm Aug2012.shp)

- 7-mile reach bank lines, August 2012 (sm Aug2012_bnkln.shp)

- 7-mile reach bank points, November 2012 (sm_ Nov2012.shp)

- 7-mile reach bank lines, November 2012 (sm Nov2012_bnkln.shp)

- 7-mile reach bank points, August 2013 (sm Aug2013.shp)

- 7-mile reach bank points, November 2015 (sm Nov2015.shp)

- 7-mile reach bank lines, November 2015 (sm Nov2015_bnkln.shp)

\section{Video Generated from Time-Lapse Images}

The Child Item titled "Time-lapse video of photographs of the Lake Sharpe shoreline near Lower Brule, South Dakota, 2013-15" contains a description of the methodology used to collect photographic data and condense it into video. The page contains links to download a general metadata file, and links to zipped folders containing specific metadata files, a folder of the photographs used to generate the video, and a time-lapse video for each of the camera sites. The camera sites were each named for a feature at the camera site. The "lodge" camera was at the Lodge site (fig. 4) near the rental hunting lodge cabins near the Lower Brule Sioux Tribe Wildlife Office. The "playground" camera was at the Playground site (fig. 4) near the recreational vehicle park on the east edge of Lower Brule. The "lagoon" camera was mounted on a tree at the Lagoon site (fig. 4) near the southeasternmost of the sewage treatment lagoons southeast of Lower Brule. As described in the metadata, two folders were needed for the videos from the Lodge and Lagoon sites. The cameras at these sites initially were mounted on trees, but they had to be moved to nearby locations when the trees were in danger of toppling into the water because of erosion as described in the "Time-Lapse Photography" section of this report. The Lodge and Lagoon sites have two folders, each numbered 1 and 2 to denote the slightly different locations of these two sites.

\section{Plate 1. Soil Type and Land Cover Interactions with Erosion Measurements near Lower Brule, South Dakota}

Plate 1 may be downloaded as a georeferenced portable document file (geo pdf) at https://doi.org/10.3133/ sir20185058. This file can be opened using Adobe ${ }^{\circledR}$ Acrobat $^{\circledR}$ or Acrobat Reader ${ }^{\circledR}$ software. Instructions for using tools are based on Adobe Acrobat Reader 2017, and may need to be modified for other Adobe software versions. Within this geo pdf, the 7-mile reach bank lines digitized from real-time kinetic-collected bank locations for each date are displayed against base-map imagery as lines of differing colors. A layers tool (accessible by clicking on the layers icon near the upper left edge) can be used to toggle which data layers are displayed. Clicking on the layers icon opens a panel that lists the layers present in the figure. Clicking on the arrow near the layers folder will expand the folder and list each layer individually. Each layer has an eye icon. Clicking on the eye icon for a specific layer allows that layer to be turned on or off. The plus and minus buttons (or the zoom drop-down box), together with panning, can be used to zoom in to an area of interest. A measuring tool is available within Acrobat Reader. Select the Tools tab near the top of the page, then click on Measure. This tool can be used to measure eroded distances between bank lines at any location within the 7-mile reach. To use this tool, click on Measuring Tool within the Measure menu. Then click a point where the distance measurement should begin, and click a second point where it should end. After clicking the second point, a Geospatial Distance Tool window will appear that displays the distance between the two clicked points. Imagery from the base map can be used to determine the locations of features and land-cover types that may affect erosion, and the soils layer may be used to compare eroded distances to soil types.

For more information about this publication, contact

Director, USGS Dakota Water Science Center, South Dakota Office

1608 Mountain View Road

Rapid City, SD 57702

(605) 394-3200

For additional information visit https://sd.water.usgs.gov

Publishing support provided by the

Rolla Publishing Service Center 


